Antarctic Science 33(5), 502-532 (2021) @ The Author(s), 2021. Published by Cambridge University Press. This is an Open Access article, distributed under the terms of the Creative Commons Attribution licence (http://creativecommons.org/licenses/by/4.0/), which permits unrestricted re-use, distribution, and reproduction in any medium, provided the original work is properly cited.

doi:10.1017/S095410202100033X

\title{
A lithostratigraphical and chronological study of Oligocene-Miocene sequences on eastern King George Island, South Shetland Islands (Antarctica), and correlation of glacial episodes with global isotope events
}

\author{
JOHN L. SMELLIE ${ }^{(1)}$, WILLIAM C. MCINTOSH ${ }^{2}$, ROWAN WHITTLE $\mathbb{1}^{3}$, ALEXA TROEDSON ${ }^{4}$ and \\ RICHARD J. HUNT ${ }^{5}$ \\ ${ }^{1}$ School of Geography, Geology \& the Environment, University of Leicester, Leicester, LE1 7RH, UK \\ ${ }^{2}$ New Mexico Bureau of Geology and Mineral Resources, New Mexico Tech, Socorro, NM 87801, USA \\ ${ }^{3}$ British Antarctic Survey, Cambridge, CBE 0ET, UK \\ ${ }^{4}$ Troedson Geosciences Consulting, Sydney, Australia \\ ${ }^{5}$ School of Earth Sciences, University of Leeds, Woodhouse Lane, Leeds, LS2 9JT, UK \\ jls55@le.ac.uk
}

\begin{abstract}
King George Island (South Shetland Islands, Antarctic Peninsula) is renowned for its terrestrial palaeoenvironmental record, which includes evidence for potentially up to four Cenozoic glacial periods. An advantage of the glacigenic outcrops on the island is that they are associated with volcanic formations that can be isotopically dated. As a result of a new mapping and chronological study, it can now be shown that the published stratigraphy and ages of many geological units on eastern King George Island require major revision. The Polonez Glaciation is dated as c. $26.64 \pm 1.43 \mathrm{Ma}$ (Late Oligocene (Chattian Stage)) and includes the outcrops previously considered as evidence for an Eocene glacial ('Krakow Glaciation'). It was succeeded by two important volcanic episodes (Boy Point and Cinder Spur formations) formed during a relatively brief interval $(<2 \mathrm{Ma}$ ), which also erupted within the Oligocene Chattian Stage. The Melville Glaciation is dated as $c$. 21-22 Ma (probably $21.8 \mathrm{Ma}$; Early Miocene (Aquitanian Stage)), and the Legru Glaciation is probably $\leq c .10 \mathrm{Ma}$ (Late Miocene or younger). As a result of this study, the Polonez and Melville glaciations can now be correlated with increased confidence with the Oi2b and Mila isotope zones, respectively, and thus represent major glacial episodes.
\end{abstract}

Received 29 December 2020, accepted 4 March 2021

Key words: ${ }^{40} \mathrm{Ar} /{ }^{39} \mathrm{Ar}$, isotope zones, Kraków Glaciation, Legru Glaciation, Melville Glaciation, Polonez Glaciation

\section{Introduction}

King George Island is the largest of the South Shetland Islands, situated in northern Antarctic Peninsula (Fig. 1). Because of the relative ease of access and generally low alteration grade compared with other areas in the Antarctic Peninsula region, the geology of the island has been subject to numerous investigations over the past several decades. This has resulted in a complicated stratigraphy that has been supported by a large number of isotopic ages, mainly determined by the $\mathrm{K}$-Ar method (see summary of published ages by Leat \& Riley 2021a). However, there is evidence for Ar loss and K-metasomatism and the validity of many of the ages is debatable (cf. Dupre 1982, Birkenmajer et al. 1990, Soliani \& Bonhomme 1994, Shiling et al. 1996, Smellie et al. 1998, Willan \& Kelley 1999, Kraus 2005,
Pańczyk et al. 2009, Nawrocki et al. 2010, 2011, Haase et al. 2012). King George Island is renowned for its terrestrial, Palaeogene-Early Miocene, high-latitude palaeoenvironmental record, preserved in sedimentary strata (e.g. Zastawniak 1981, Zastawniak et al. 1985, Birkenmajer \& Zastawniak 1989, Cao 1992, 1994, Dutra \& Batten 2000, Poole et al. 2001, Hunt \& Poole 2003, Fontes \& Dutra 2010, Cantrill \& Poole 2012, Mozer 2012, 2013, Warny et al. 2019). It is an important location for understanding the environmental evolution of Antarctica and up to four glacial episodes have been postulated. However, the validity of one has been criticized (Dingle \& Lavelle 1998, Troedson \& Smellie 2002) and a precise correlation with global isotope zones (sensu Miller et al. 1991) remains uncertain (Troedson \& Riding 2002, Troedson \& Smellie 2002). A fuller understanding of Antarctica's environmental history is 


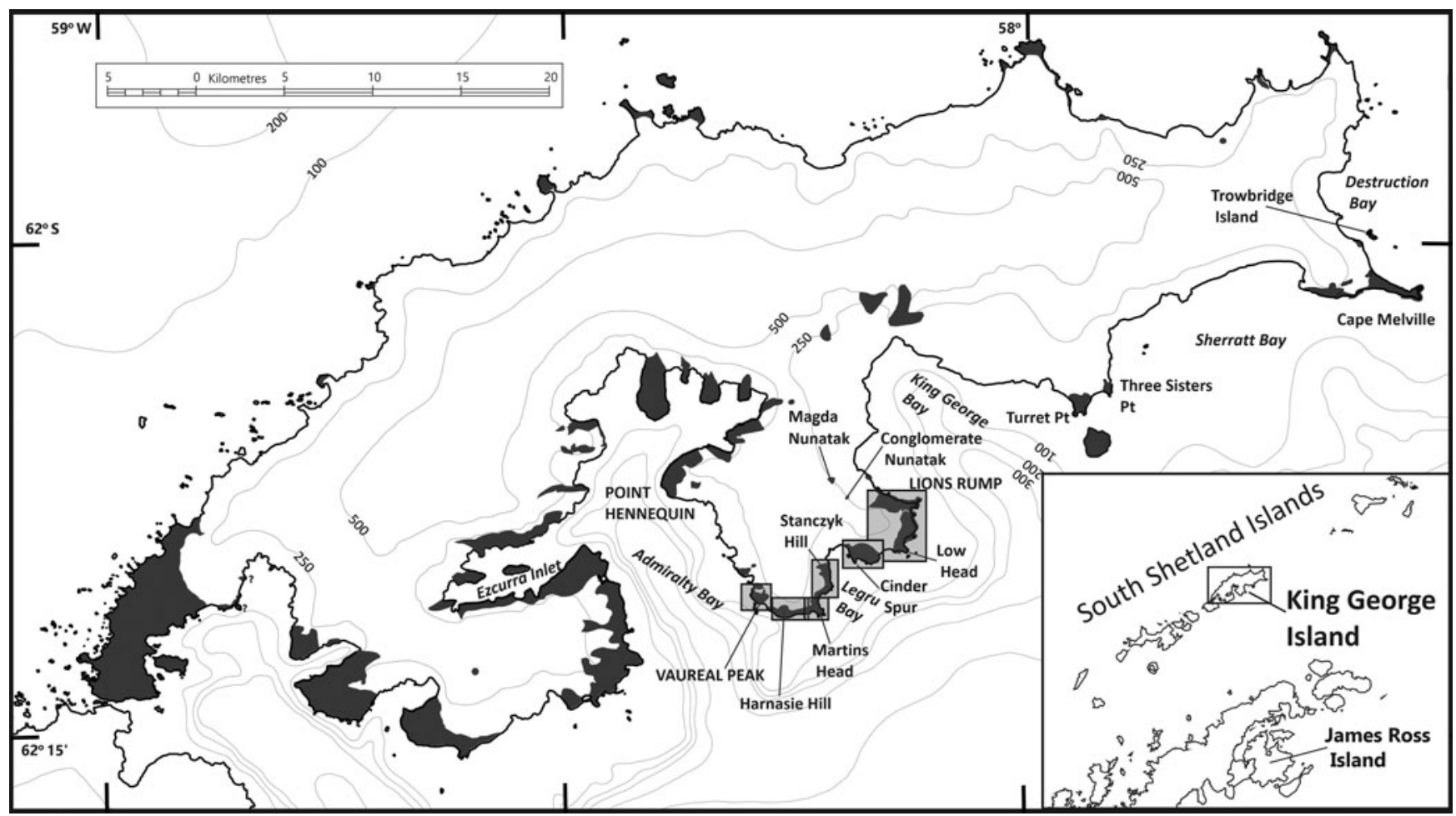

Fig. 1. Map of King George Island, showing the distribution of rock outcrops and the areas included in this study (shaded boxes). The inset shows the location of the South Shetland Islands (including King George Island) in the northern Antarctic Peninsula region.

reliant on having a well-defined stratigraphy linked to a well-constrained chronology. As a result of our study, it is clear that many aspects of the stratigraphy and chronology of King George Island are questionable and require substantial revision.
The islands are largely constructed of the products of arc volcanism, mainly lavas and clastic rocks with fewer small outcrops of coeval plutons (e.g. Smellie et al. 1984, Shen 1994, Dutra \& Batten 2000, Birkenmajer 2001 and references therein, Mozer 2012, 2013). The volcanism is

Table I. Stratigraphy of eastern King George Island (after Birkenmajer 1982).

\begin{tabular}{|c|c|c|c|c|}
\hline Group & Formation & Member & Formation age & Glacial episode \\
\hline $\begin{array}{l}\text { Cape Syrezol (hypabyssal } \\
\text { intrusions) }\end{array}$ & & & Early-Middle Miocene (21.9-14.1 Ma) & \\
\hline \multirow[t]{3}{*}{ Moby Dick } & Cape Melville & & Early Miocene (c. 22.6 $\pm 0.4 \mathrm{Ma})$ & $\begin{array}{l}\text { Melville }(<23.6 \mathrm{Ma} \\
>20 \mathrm{Ma})\end{array}$ \\
\hline & Destruction Bay & & $\begin{array}{l}\text { Latest Oligocene/earliest Miocene }(25.3 \pm 0.8 \mathrm{Ma} \text { or } \\
23.6 \pm 0.7 \mathrm{Ma})\end{array}$ & \\
\hline & Sherratt Bay & & Latest Oligocene or older $(>23.6 \pm 0.7 \mathrm{Ma})$ & \\
\hline \multirow[t]{4}{*}{ Legru Bay } & Vauréal Peak & & Late Oligocene $(<28.0 \pm 3.1 \mathrm{Ma})$ & Legru (c. 30-26 Ma) \\
\hline & Martins Head & & Late Oligocene $(25.7 \pm 1.3 \mathrm{Ma})$ & \\
\hline & Harnasie Hill & & Late Oligocene $(<29.5 \pm 2.1 \mathrm{Ma} ;>25.7 \pm 1.3 \mathrm{Ma})$ & \\
\hline & Dunikowski Ridge & & Late Oligocene $(30.8 \pm 2.0 \mathrm{Ma} ; 29.5 \pm 2.1 \mathrm{Ma})$ & \\
\hline \multirow[t]{4}{*}{ Chopin Ridge } & Wesele Cove & & Mid-Oligocene $(<29.5 \mathrm{Ma} ;>23.6 \mathrm{Ma})$ & \\
\hline & Boy Point & & Mid-Oligocene (> 23.6 $\pm 0.3 \mathrm{Ma})$ & \\
\hline & Polonez Cove & $\begin{array}{l}\text { Oberek Cliff } \\
\text { Siklawa } \\
\text { Low Head } \\
\text { Krakowiak } \\
\text { Glacier }\end{array}$ & Early Oligocene (33-32 Ma) & Polonez (33-32 Ma) \\
\hline & $\begin{array}{l}\text { Mazurek Point } \\
\text { Magda Nunatak } \\
\text { Complex }\end{array}$ & & $\begin{array}{l}\text { Late Cretaceous-Late Eocene }(74.0-34.4 \pm 0.5 \mathrm{Ma}) \\
\text { Early Eocene }(49.5 \pm 5.0 \mathrm{Ma})\end{array}$ & Kraków \\
\hline
\end{tabular}

Note: All ages are by K-Ar except for the Polonez Cove Formation, which is palaeontological. 
dominated by basalt to andesite lavas with island arc tholeiite to calc-alkaline compositions (Smellie et al. 1984, Birkenmajer et al. 1991a, Machado et al. 2005, Haase et al. 2012, Leat \& Riley 2021b). It apparently proceeded in a series of volcanic 'flare-ups' (sensu Paterson \& Ducea 2015) with peaks at c. 130-110, 90-70, 60-40 and 30-20 Ma (Willan \& Kelley 1999, Fretzdorff et al. 2004, Haase et al. 2012, Smellie 2020, Leat \& Riley 2021a). The main axis of active arc volcanism also migrated in a north-easterly or, more likely, south-easterly direction (Pankhurst \& Smellie 1983, Nawrocki et al. 2021a, Smellie 2021a), which resulted in the youngest volcanic rocks, of Oligocene and Early Miocene age, being confined to eastern King George Island. Rocks of comparable age are very scarce elsewhere in Antarctica (e.g. Hannah et al. 2001). The King George Island strata contain evidence for several glaciations, inferred to be variably of local to regional (pan-Antarctic) extent, together with several interglacials, some of which may have included alpine glaciers (Birkenmajer 1990, Birkenmajer et al. 2005). However, recent dating studies, mainly by the ${ }^{40} \mathrm{Ar} /{ }^{39} \mathrm{Ar}$ method, have challenged the validity of several of the glacial and interglacial episodes (e.g. Nawrocki et al. 2011, Smellie et al. 2021). Moreover, apart from Cape Melville and the area between Lions Rump and Low Head (Fig. 1), previous mapping on eastern King George Island has been only at a reconnaissance level (cf. Birkenmajer 1982, Smellie et al. 1984, Troedson \& Riding 2002, Troedson \& Smellie 2002). The type sections for the palaeoenvironmentally important Polonez Cove and Cape Melville formations are well studied, but at least ten additional formations are currently recognized (Table I; e.g. Birkenmajer 1980, 1982, 1987, 1995b, Birkenmajer \& Weiser 1985, Porebski \& Gradzinski 1987, 1990, Birkenmajer \& Butkiewicz 1988, Troedson \& Riding 2002, Troedson \& Smellie 2002).

The principal focus of this paper is a description of the lithostratigraphy of Oligocene sedimentary and associated volcanic sequences on eastern King George Island and to present the strata within an improved chronological framework supported by new ${ }^{40} \mathrm{Ar} /{ }^{39} \mathrm{Ar}$ isotopic ages. Together with the revised lithostratigraphy, the new ages significantly expand our understanding of the chronology of Cenozoic glacial episodes in Antarctica and enable an improved correlation with global climate events (e.g. Hunt \& Poole 2003, Francis et al. 2008, Cantrill \& Poole 2012).

\section{Methods}

Fieldwork was undertaken on King George Island on 12 January-16 March 1996, 19 January-3 March 1999, 9-18 February 2014 and for 4 weeks in January-February 2019. Detailed mapping, largely on a bed-by-bed basis, was directly onto 1:10,000-scale Falkland Islands Dependencies Aerial Survey Expedition (FIDASE; 1958) and HMS Endurance (1979) air photographs provided by the British Antarctic Survey. Although the maps of the studied localities included in this paper show the solid geology, maps based on the distribution of actual rock exposure are also included for comparison (Supplemental Information S1). Rock samples were taken for petrography, whole-rock geochemistry and ${ }^{40} \mathrm{Ar} /{ }^{39} \mathrm{Ar}$ isotopic dating. A total of 200 thin sections were examined. The isotopic dating was carried out at the New Mexico Geochronology Research Laboratory and at Leeds University (methods described in Supplemental Information S2). All samples are archived in the British Antarctic Survey Geological Specimens Collection, Cambridge, England. Full details of the dating results are also included in Supplemental Information S2.

\section{Stratigraphy}

Previous geological studies of eastern King George Island established a relatively complicated stratigraphy involving numerous formations ranging in age between the Late Cretaceous and Early Miocene (Table I). The Oligocene formations rest unconformably on a local 'basement' composed of andesite lavas, which provide a maximum age for the strata. Previously thought to extend back to the Late Cretaceous (74 Ma; Birkenmajer \& Gaździcki 1986), the basement lavas are now known to be Middle Eocene (c. 45 Ma; Smellie et al. 1984, Pańczyk \& Nawrocki 2011, Smellie et al. 2021). Numerous Oligocene formations have been defined (Table I). Most are volcanic, but they include the mainly sedimentary (glacial-marine) Polonez Cove Formation, which is the oldest Oligocene geological unit recognized. Isotopic dating, by the K-Ar method, suggested a range of ages for the Oligocene strata between $c .33$ and < 25.7 Ma (Birkenmajer 1989). Several of the ages are either simply maxima or minima and some conflict with the observed order of succession. Moreover, the inferred palaeontological age of the highly fossiliferous Polonez Cove Formation (c. 33-32 Ma) is older than the age determined by ${ }^{87} \mathrm{Sr} /{ }^{86} \mathrm{Sr}$ isotopic dating of shelly fossils (29.8 $\pm 0.6 \mathrm{Ma}$; Dingle et al. 1997, Dingle \& Lavelle 1998), although recent unpublished ${ }^{87} \mathrm{Sr} /{ }^{86} \mathrm{Sr}$ isotopic studies may have narrowed the age gap (K. Krajewski, cited by Warny et al. 2019). However, the Polonez Cove Formation is characterized by abundant reworked older fossils, and it has been difficult to determine a reliable palaeontological age (see discussion by Birkenmajer 2001, and below). Moreover, the shelly fossils dated by the ${ }^{87} \mathrm{Sr} /{ }^{86} \mathrm{Sr}$ method showed poor preservation, and any ages must be treated with caution (acknowledged by Dingle et al. 1997). Taken together with suspicion of Ar loss and K-metasomatism affecting 


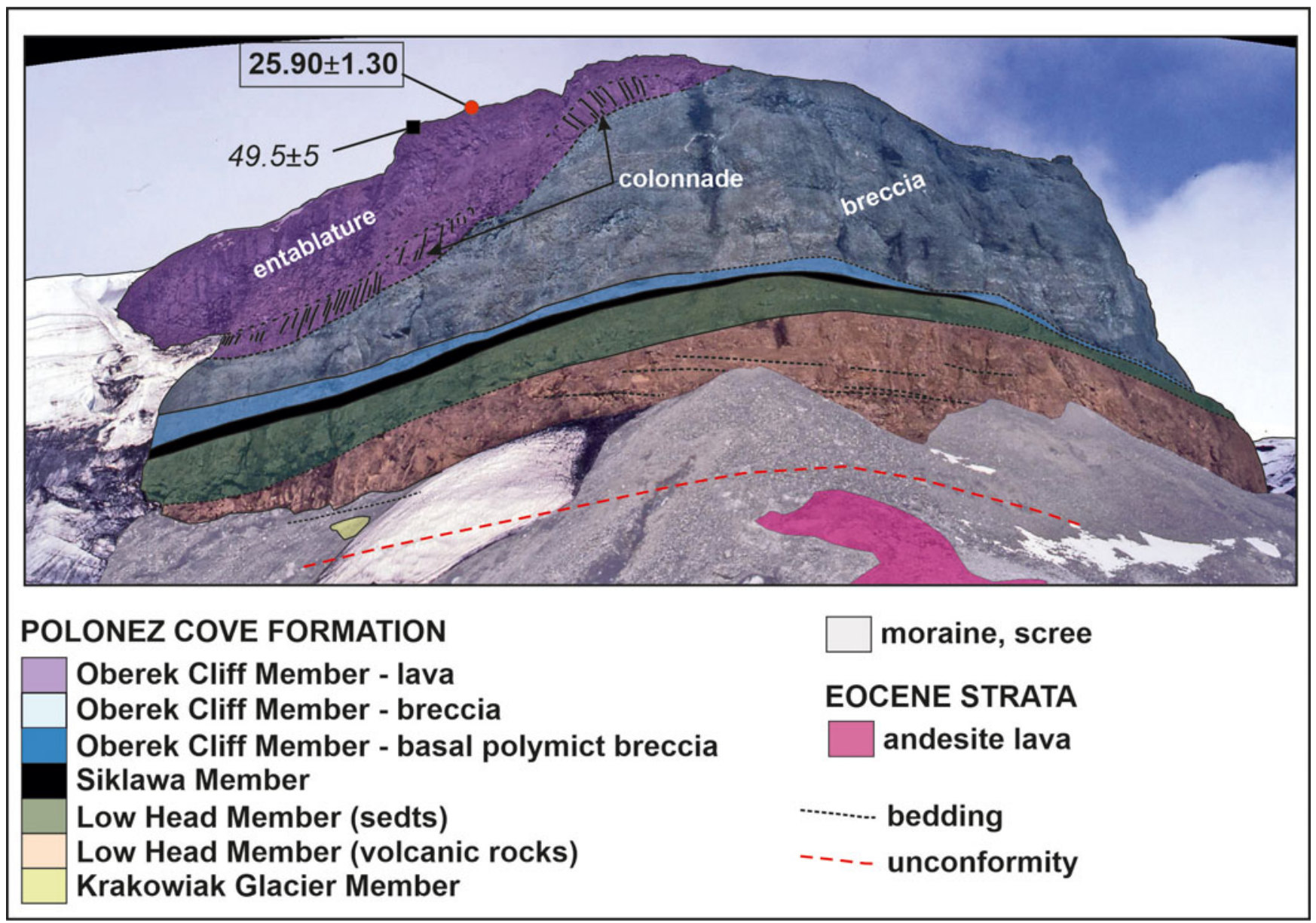

Fig. 2. View of Magda Nunatak, looking west, with the geology indicated. There is a remarkable and conspicuous similarity with the internal stratigraphy of the Polonez Cove Formation, exposed just $3 \mathrm{~km}$ to the south-east, and with which the outcrop is now correlated. An outcrop of the Bayview Member is also present within the sequence, out of sight at right, and a tiny outlier of the Chlamys Ledge Member occurs at the summit (also out of sight; Troedson \& Smellie 2002). The locations of the two dated samples shown are approximate. The rock face is $c .60 \mathrm{~m}$ high (estimated).

the published $\mathrm{K}-\mathrm{Ar}$ ages, the Oligocene-Miocene chronology is poorly established and the ages of all the formations require verification.

\section{Magda Nunatak Complex (abandoned stratigraphical unit)}

Magda Nunatak Complex is the name used for an association of lava, lava breccia ('hyaloclastite') and fossiliferous marine sedimentary strata that crop out only at Magda Nunatak in eastern King George Island (Fig. 1). Despite an early prescient study, which attributed the sedimentary rocks to the Polonez Cove Formation, but without citing supporting evidence (Tokarski et al. 1981), the capping lava was correlated with the supposedly long-lived (Late Cretaceous-Oligocene) Mazurek Point Formation (Birkenmajer 1982). Subsequent K-Ar dating of the capping lava yielded an Eocene age (49.5 $\pm 5 \mathrm{Ma})$, thus apparently confirming the correlation, and the age was used to suggest the existence of an Eocene glacial episode called the Kraków Glaciation (Birkenmajer et al. 1986). However, ${ }^{87} \mathrm{Sr} /{ }^{86} \mathrm{Sr}$ dating of shelly material in the Magda Nunatak sediments yielded an age of $28.5 \pm 0.64 \mathrm{Ma}$ (Dingle \& Lavelle 1998). Although ${ }^{87} \mathrm{Sr} /{ }^{86} \mathrm{Sr}$ ages are determined with reference to the Cenozoic seawater ${ }^{87} \mathrm{Sr} /{ }^{86} \mathrm{Sr}$ curve and are therefore subject to variable errors depending on the slope of that curve (for methodology, see McArthur et al. 2001), the ${ }^{87} \mathrm{Sr} /{ }^{86} \mathrm{Sr}$ ages obtained at Magda Nunatak make an Eocene age for the sequence unlikely. Moreover, Troedson \& Smellie (2002) pointed to the strong lithological similarity with the Polonez Cove Formation and provided a preliminary ${ }^{40} \mathrm{Ar} /{ }^{39} \mathrm{Ar}$ age (lacking supporting data) slightly younger than the $\mathrm{Sr}$ age. Here we re-emphasize the remarkable similarity in lithofacies between the two outcrops, which is essentially on a bed-by-bed basis (Fig. 2; cf. Troedson \& Smellie 2002). Together with a new ${ }^{40} \mathrm{Ar} /{ }^{39} \mathrm{Ar}$ age reported here (see later), all doubt is removed that the Eocene age 


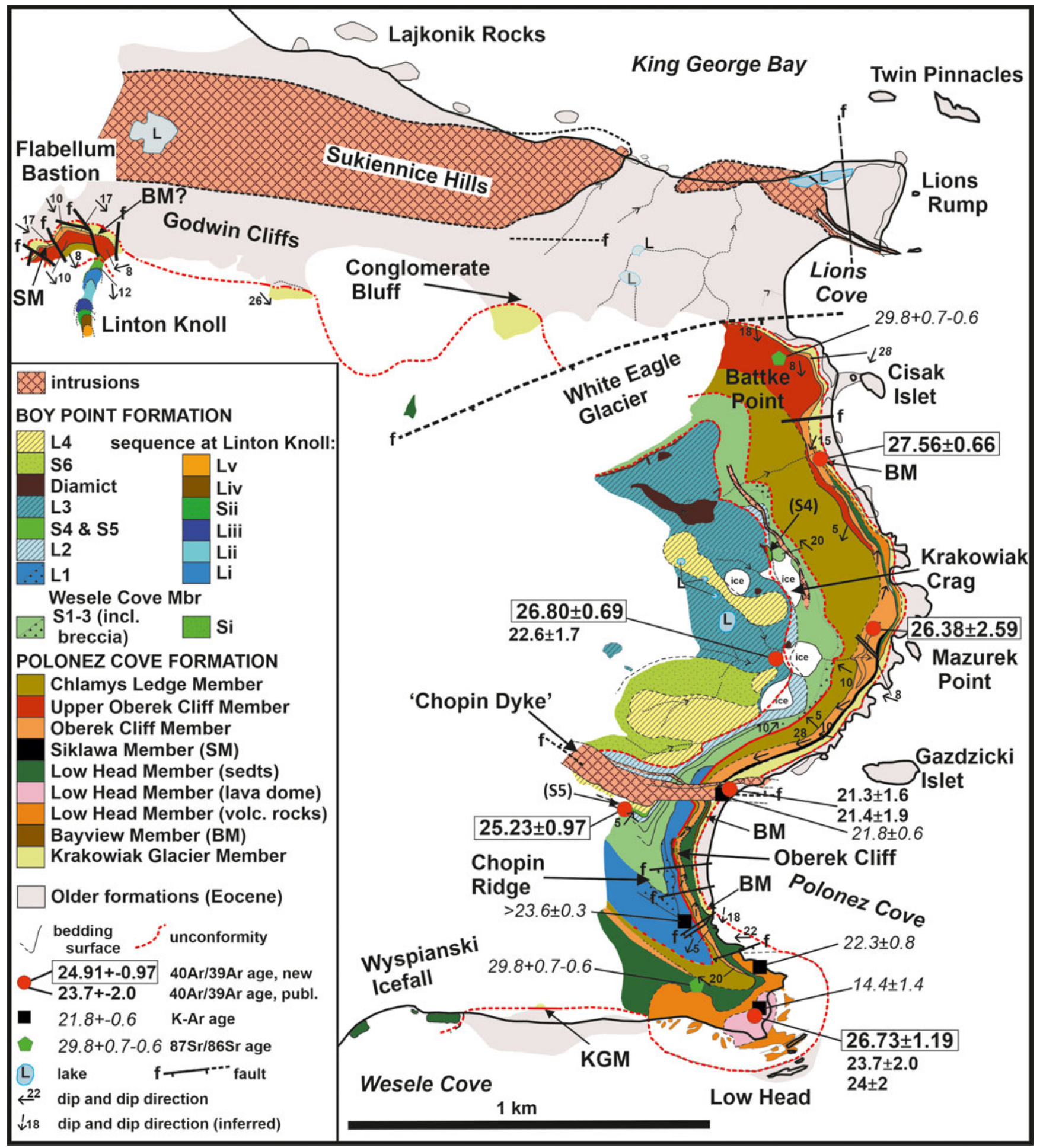

Fig. 3. Geological map of the Low Head-Lions Rump-Godwin Cliffs area, eastern King George Island. The 'upper Oberek Cliff Member' depicted at Battke Point and Godwin Cliffs is a fossiliferous sandy-gravelly deposit (broadly comparable to subunit 'OC3' of Troedson \& Smellie 2002) with a remarkable resemblance to similarly fossiliferous sedimentary rocks of the Low Head Member (especially subunit 'L2' of Troedson \& Smellie 2002).

for the Magda Nunatak Complex is incorrect and it is indistinguishable from the Polonez Cove Formation, with which it is unequivocally correlated. Thus, there is no justification for retaining the Magda Nunatak Complex name for the outcrop and it is suggested that it should be removed from the stratigraphical lexicon. 


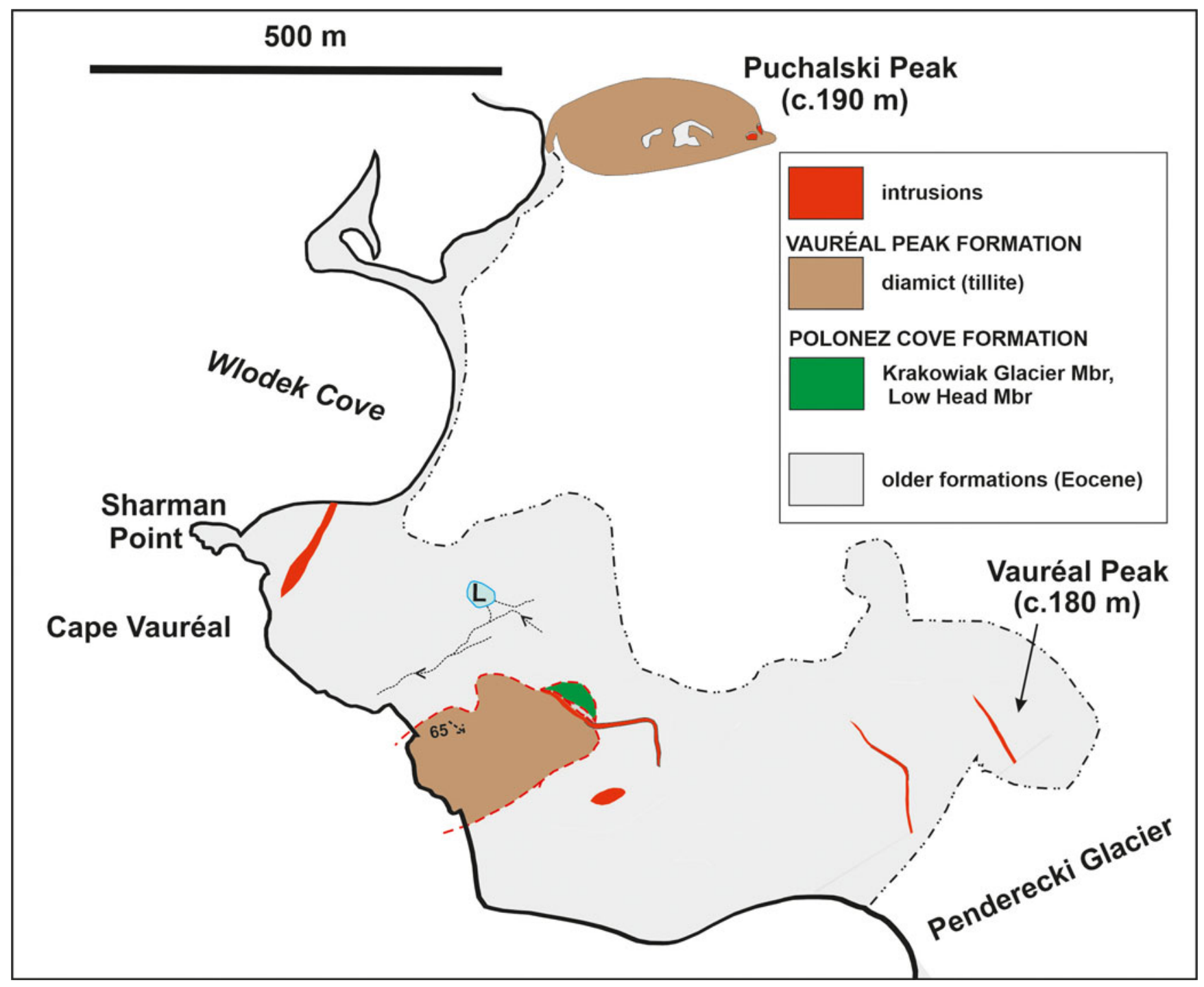

Fig. 4. Geological map of the Vauréal Peak area, eastern King George Island. See Fig. 3 for explanation of additional symbols.

Hervé Cove tillite (name not recommended)

Additional evidence for Eocene ice conditions on King George Island was cited by Birkenmajer et al. (2005), who suggested that a volcanic diamictite with supposedly exotic erratics on the south coast of Ezcurra Inlet (Fig. 1) was also a glacial deposit (tillite). With an inferred age of $c$. 45-41 Ma (by K-Ar), overlapping within the error of the K-Ar age for the Magda Nunatak Complex, the deposit was called the Herve Cove tillite, and it was believed to be associated with volcanoes with ice-capped summits. The age of the deposit was subsequently shown to be $c .49 \mathrm{Ma}$ (by ${ }^{40} \mathrm{Ar} /{ }^{39} \mathrm{Ar}$ and U-Pb dating; Nawrocki et al. 2011). However, alpine glaciers are unlikely to be a source of exotic (i.e. non-local) erratics. The erratic lithologies were not described, but volcanic diamictites similar in lithofacies to the 'Hervé Cove tillite' are common in Eocene sequences elsewhere on King George Island and lack exotic erratics (Smellie et al. 2021). The evidence for glacial deposition and alpine glaciers on King George Island during the Eocene is thus currently unproven (Mozer 2013, Smellie et al. 2021; see also Nawrocki et al. 2011), and it is recommended that the use of the name 'Hervé Cove tillite' should be discontinued unless a glacial origin can be much better demonstrated.

\section{Polonez Cove Formation}

Because of its association with an important glacial episode (the Polonez Glaciation), the Polonez Cove Formation is one of the most intensively investigated geological units in the South Shetland Islands (e.g. Barton 1965, Birkenmajer 1980, 1982, 1987, 1995a, Paolo \& Tokarski 1982, Gazdzicki \& Pugaczewska 1984, 


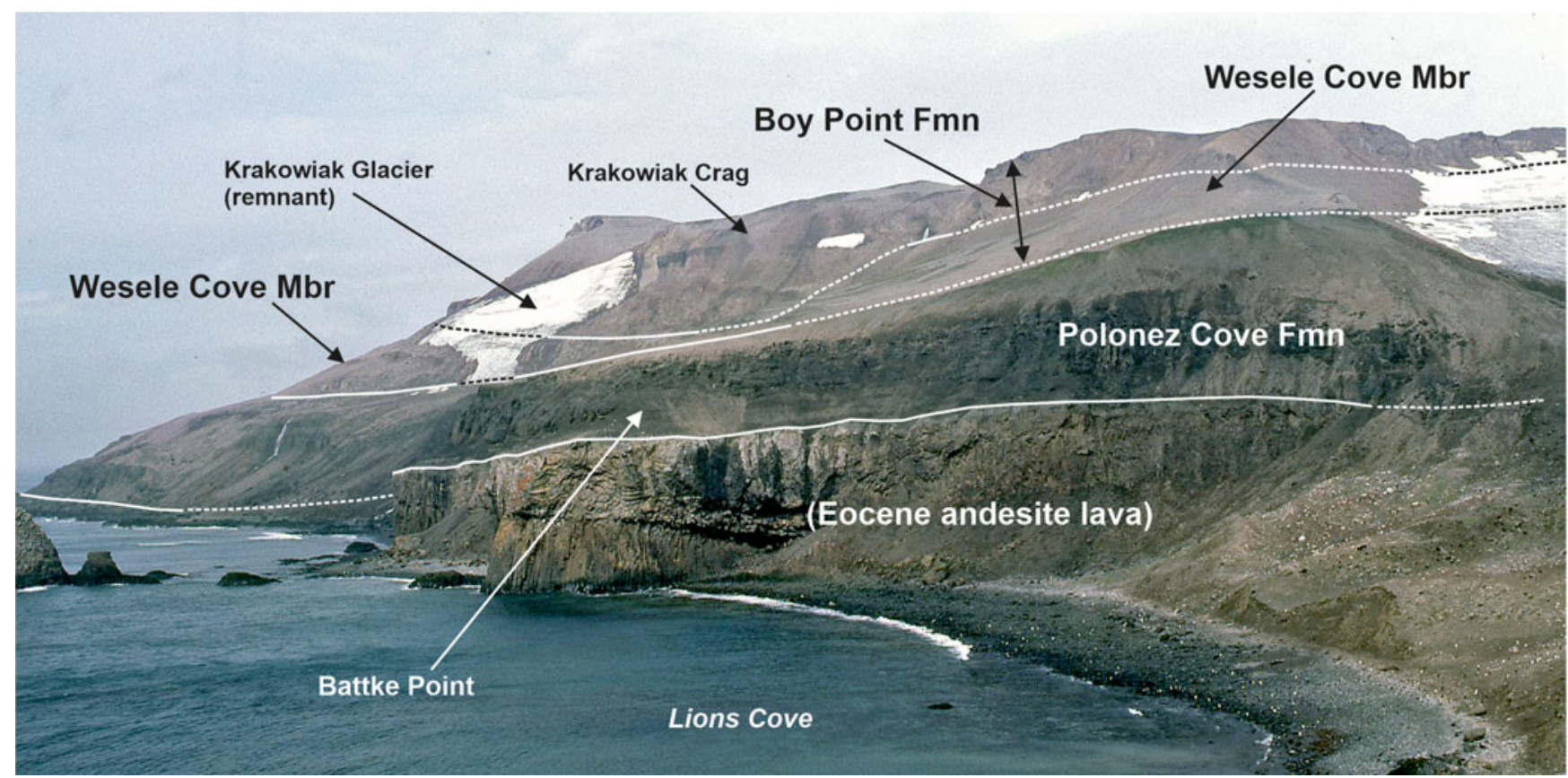

Fig. 5. View looking south from Lions Rump to Battke Point and Krakowiak Crag, showing the sequence of formations. The view illustrates clearly how the Wesele Cove Member locally intervenes between the Polonez Cove and Boy Point formations, contradicting the previously published stratigraphy (i.e. Birkenmajer 1982, 2001). The amount of relief shown is $c .200 \mathrm{~m}$ (estimated). The dramatic reduction in the extent of Krakowiak Glacier is evident when this image (taken in January 1996) is compared with that taken in 1976 by Smellie et al. (1984, fig. 40).

Birkenmajer \& Wieser 1985, Porebski \& Gradzinski 1987, 1990, dos Santos et al. 1990, Smellie \& Rex 1993, Smellie et al. 1998, Troedson \& Smellie 2002, Quaglio et al. 2008, 2014, Nawrocki et al. 2021b). The formation is continuously exposed in a $2.0 \mathrm{~km}$-long cliff section between Low Head and Lions Rump, but it also includes substantial outcrops at Godwin Cliffs and Magda Nunatak and small outliers at Vauréal Peak and Three Sisters Point (Figs 1-4). The maximum thickness of the formation varies from $58 \mathrm{~m}$ at Godwin Cliffs to $59 \mathrm{~m}$ at Mazurek Point and c. $63 \mathrm{~m}$ (estimated) at Magda Nunatak (Troedson \& Smellie 2002). It rests unconformably on an uneven surface eroded into andesite lavas of the Middle Eocene Hennequin Formation (also called the Mazurek Point Formation; Pańczyk \& Nawrocki 2011, Smellie et al. 2021). The basal surface has a general relief of $c$. 15-20 m, with local hollows or channels up to $10 \mathrm{~m}$ deep (e.g. at Magda Nunatak and Mazurek Point). The lava is sometimes sheared and brecciated in the vicinity of the contact, with diamict injected into fractures between clasts (Birkenmajer 1995a, Troedson \& Smellie 2002, and unpublished observations by the authors). Glacial striations and roche moutonée landforms have also been described at Three Sisters Point (Paulo \& Tokarski 1982, Birkenmajer 1995a). The boundary with the overlying Polonez Cove Formation was regarded as an angular unconformity by Birkenmajer (1995a). However, it is probably better regarded as a disconformity. The contact is planar and sub-horizontal. Despite the abundance of fossils in the Polonez Cove Formation, particularly in its type area, many have been recycled from older strata (see Supplemental Information S3 \& S4). Even contemporary fossils have relatively long age ranges, and it has only proven possible to determine an imprecise Oligocene palaeontological age (Gazdzicki \& Pugaczewska 1984, Gaździcka \& Gaździcki 1985, Birkenmajer \& Gaździcki 1986, and see later discussion).

The most complete sections of the Polonez Cove Formation occur between Low Head and Lions Rump and at Magda Nunatak (Figs 1, 2 \& 5). The formation has been divided into six members, with further division of the members into multiple subunits on a sedimentological basis (Figs 2 \& 6; Troedson \& Smellie 2002; cf. Birkenmajer 1982, Porebski \& Gradzinski 1987). The earliest-formed deposit is the diamictite-dominated Krakowiak Glacier Member (Fig. 7a). It contains basal lenses of lodgement tillite but is largely formed of debris flow deposits and minor sandstones laid down in an ice-front environment and from icebergs. It is spectacularly polymict, with abundant erratics derived from the South Shetland Islands, Antarctic Peninsula and East Antarctica (Birkenmajer \& Wieser 1985, Troedson \& Smellie 2002). 


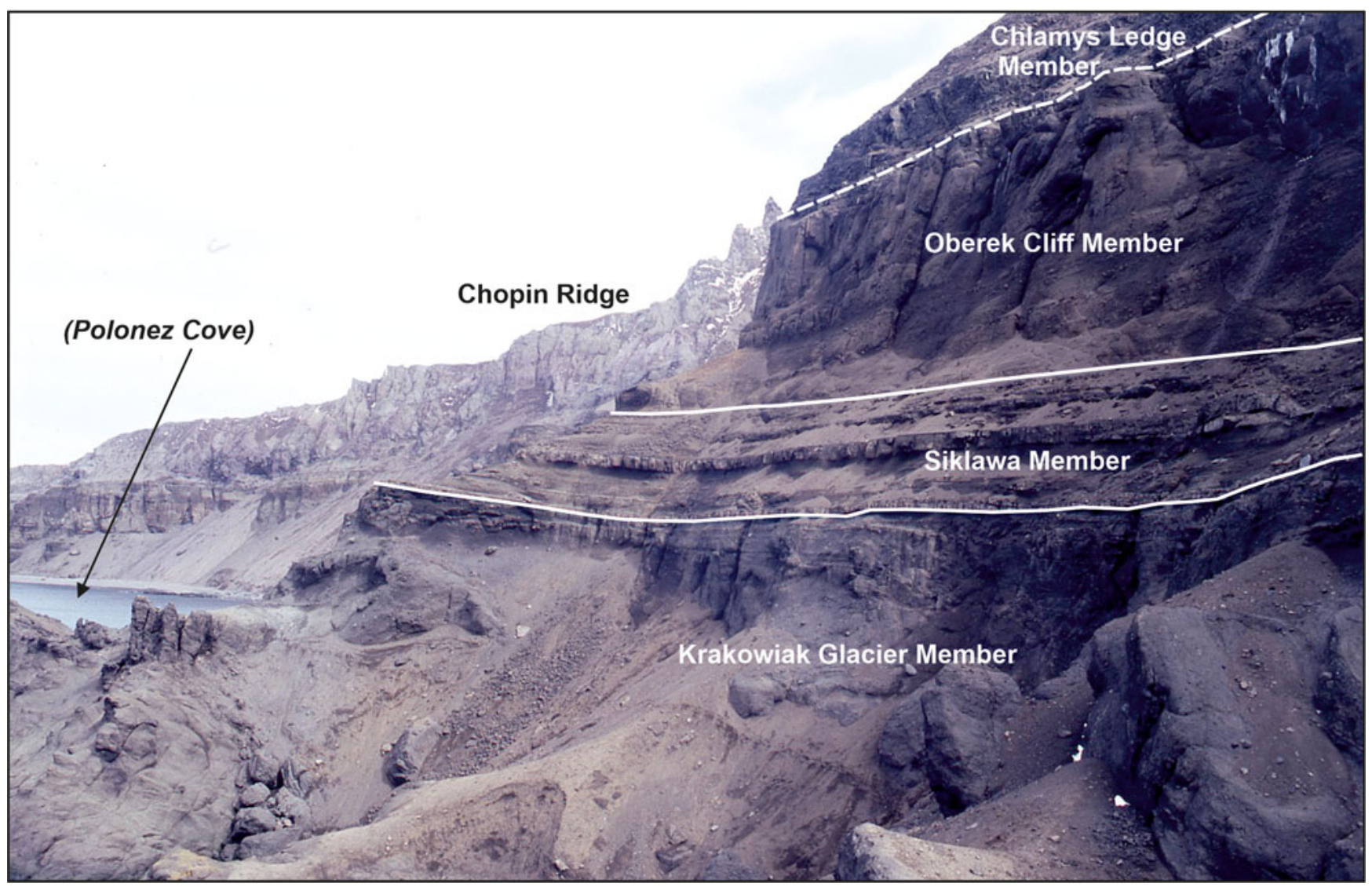

Fig. 6. View of the Polonez Cove Formation showing its constituent members, looking south from Mazurek Point. Approximately $45 \mathrm{~m}$ of section is shown in the foreground.

Multiple sources probably situated in the southern Antarctic Peninsula, Haag Nunataks, Ellsworth Mountains, Transantarctic Mountains and, speculatively, Gamburtsev Mountains were demonstrated by Nawrocki et al. (2021b) on the basis of $\mathrm{U}-\mathrm{Pb}$ isotopic ages of zircons obtained from a small selection of the erratics. The distal provenance of many erratics led Birkenmajer \& Weiser (1985) to suggest an association with a grounded pan-Antarctic regional ice sheet, but Troedson \& Smellie (2002) suggested that the distal erratics were probably reworked (i.e. dropped by far-travelled icebergs, at least some of which were sourced in East Antarctica, and subsequently reincorporated in marine-based ice sourced locally in the South Shetland Islands).

All of the members overlying the Krakowiak Glacier Member have a predominantly local basalt source, and some contain subunits that are entirely volcanic (Fig. 7b-d). The members alternate between sparsely fossiliferous, planar-bedded, generally fine-grained sediments (mainly sandstones) formed in relatively deep water (Bayview, Siklawa and Chlamys Ledge members); locally fossiliferous coarse epiclastic fan deltas sourced in recently active volcanism (subunits of the Low Head and Oberek Cliff members); and gravelly conglomeratic sediments with prominent channels and cross-stratification, typically highly fossiliferous and characteristic of deposition under relatively shallow-water high-energy conditions (other (upper) subunits of the Low Head and Oberek Cliff members). The entirely volcanic subunits consist of lava-fed deltas (in the Low Head and Oberek Cliff members; Porebski \& Gradzinski 1990) and a co-genetic association of breccia with a central plug-like mass that were collectively formed during submarine extrusion of a highly crystalline lava dome (Smellie et al. 1998).

The extent of the Bayview and Siklawa members mapped during our study mirrors that shown by Troedson \& Smellie (2002) but differs slightly in detail, as follows: 1) it is uncertain that the Siklawa Member continues to the south of the Chopin Dyke, its structural position there being represented by similar-looking thin-bedded, monomict bottom-set beds of an Oberek Cliff Member fan delta; and 2) the Bayview Member, best developed at Magda Nunatak (Troedson \& Smellie 2002), is everywhere else represented by small, erosionally isolated lenses (locations marked on Fig. 3), one of which (south of Chopin Dyke) was previously interpreted as part of the Low Head Member (Fig. 7b; 

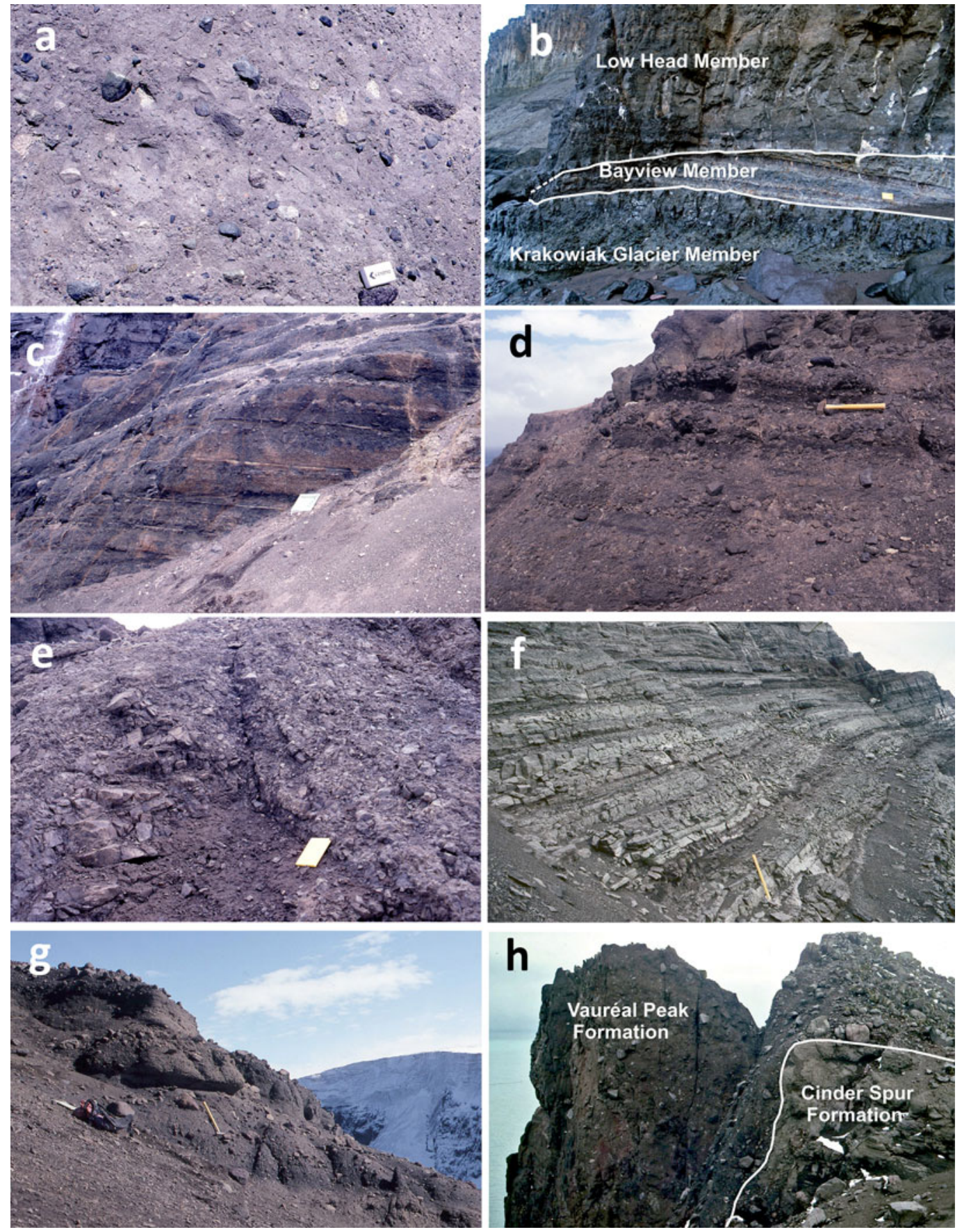

Fig. 7. Compendium of photographs showing representative lithofacies in the Oligocene volcanic and sedimentary outcrops on eastern King George Island. a. Massive diamict; Krakowiak Glacier Member (Polonez Cove Formation) at Godwin Cliffs. The eraser is $5 \mathrm{~cm}$ long. b. Thinly stratified strata of the Bayview Member sandwiched between the Krakowiak Glacier and Low Head members (Polonez Cove Formation); beach crag c. $350 \mathrm{~m}$ south of Chopin Dyke; the field notebook is $16 \mathrm{~cm}$ long. c. Unusually well-defined graded beds of monomict fine lava breccia within a lava-fed delta at Godwin Cliffs; Oberek Cliff Member (Polonez Cove Formation); the mapping case is $30 \mathrm{~cm}$ in width. d. Crude massive beds of breccio conglomerate with dispersed white-coloured chlamys fragments, part of a lava-sourced fan delta at Battke Point; Low Head Member (Polonez Cove Formation); the hammer is $35 \mathrm{~cm}$ in length. e. Pervasively fractured and brecciated lava of the Boy Point Formation at Linton Knoll; the field notebook is $16 \mathrm{~cm}$ long. f. Well-stratified, pale-coloured sedimentary beds of sequence type 1 at Stamp Buttress (Cinder Spur Formation); the hammer is $c .70 \mathrm{~cm}$ in length. g. Crudely bedded gravelly breccio conglomerates of sequence type 2 at Martins Head (Cinder Spur Formation); the hammer is c. $70 \mathrm{~cm}$ long. h. Massive diamict of the Vauréal Peak Formation unconformably draping sedimentary rocks of the Cinder Spur Formation (sequence type 1) at the summit of Cape Syrezol; note how the diamict adheres to an almost vertical face cut in the older rocks; the large boulder in the foreground at right is $c .30 \mathrm{~cm}$ in length. 


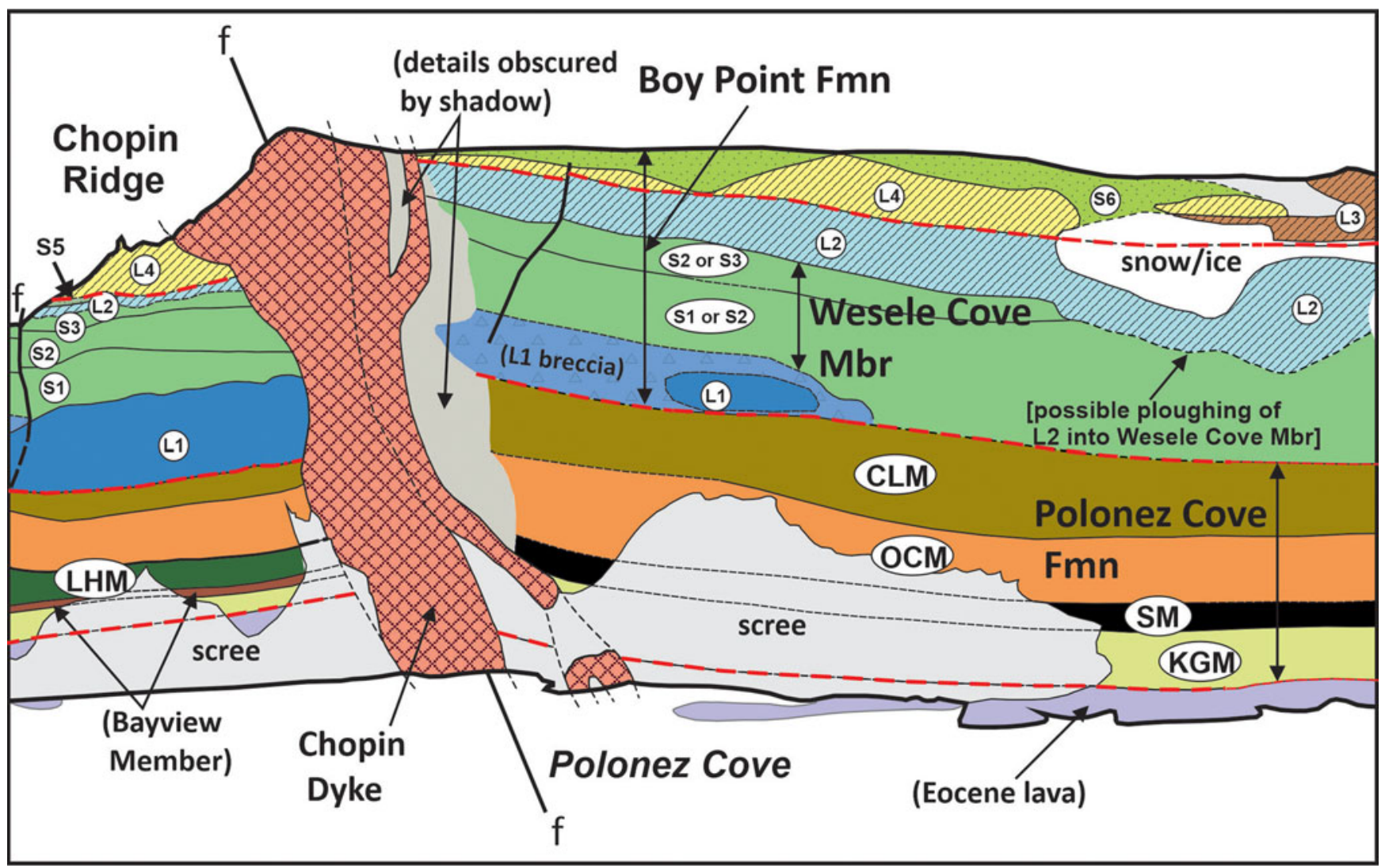

Fig. 8. Sketched view of Oberek Cliff (c. $200 \mathrm{~m}$ high) showing the stratigraphical units present, including the large Chopin Dyke. Note how lava L2 of the Boy Point Formation appears to plough into sediments of the Wesele Cove Member at right. Note also that S6 probably underlies L6 (view affected by foreshortening). Because exposures are discontinuous, it cannot be proven that sedimentary sequences S4 (not in view), S5 and S6 are different units. They occupy a similar stratigraphical position. Colours used are explained in Fig. 3. CLM = Chlamys Ledge Member; KGM = Krakowiak Glacier Member; LHM = Low Head Member; OCM = Oberek Cliff Member; $\mathrm{SM}=$ Siklawa Member.

Porebski \& Gradzinski 1987, plate 7(2); cf. Quaglio et al. 2014).

The outcrop at Three Sisters Point is a small relict, measuring just $100 \mathrm{~m}$ long by $c .70 \mathrm{~m}$ wide (Birkenmajer 1995a). It consists of diamictite and fossiliferous marine conglomerate correlated with the Krakowiak Glacier and Low Head members, respectively. The presence of striations and roche moutonée landforms cut in the basement lava noted by Paulo \& Tokarski (1982; see also Birkenmajer 1995a) have not been observed in other outcrops of the formation. Moreover, similar features also occur on top of the overlying Polonez Cove Formation at Three Sisters Point, and their orientations are consistent with modern topography. Their origin is therefore ambiguous and they thus might all have been caused by recent glacial action (observations of AT). Two even smaller outcrops were mapped at Vauréal Peak by Birkenmajer (1982). Polonez Cove Formation diamictite (Krakowiak Glacier Member?), which was shown close to the summit of Vauréal Peak at c. $180 \mathrm{~m}$ above sea level, was not observed during our investigation. However, a small outlier is present midway between Cape Vauréal and Vauréal Peak (Fig. 4). Two lithofacies are present and, as at Three Sisters Point, have been correlated with the Krakowiak Glacier and Low Head members (Birkenmajer 1982, Birkenmajer et al. 1989, Quaglio et al. 2008). At both localities, the Krakowiak Glacier Member comprises mainly massive diamictite with abundant erratic clasts. The Low Head Member at Three Sisters Point has not been described (cf. Birkenmajer 1995a, fig. 4), but at Vauréal Peak it is a crudely stratified sequence c. $10 \mathrm{~m}$ thick, dominated by massive pebbly diamictite alternating with sandy fine conglomerate and minor sandstone. It is sparsely fossiliferous (Quaglio et al. 2008).

\section{Boy Point Formation (redefined stratigraphical unit)}

Previous studies divided the strata above the Polonez Cove Formation into two formations: a lower Boy Point Formation, composed of felsic-intermediate lavas, and an 
Table II. Stratigraphy of eastern King George Island (this paper).

\begin{tabular}{|c|c|c|c|c|}
\hline Group & Formation & Member & Formation age & Glacial episode \\
\hline \multirow[t]{3}{*}{ Moby $\operatorname{Dick}^{a}$} & Cape Melville & & Early Miocene (c. 22-21 Ma) & Melville (c. 22-21 Ma) \\
\hline & Destruction $\mathrm{Bay}^{b}$ & & Latest Oligocene (c. 25 or $24 \mathrm{Ma}$ ) & - \\
\hline & Cinder Spur ${ }^{c}$ & & Late Oligocene $(25.01 \pm 1.11 \mathrm{Ma})$ & - \\
\hline \multirow[t]{6}{*}{ Chopin Ridge } & Boy Point ${ }^{d}$ & Wesele Cove ${ }^{d}$ & Late Oligocene $(26.02 \pm 0.83 \mathrm{Ma})$ & - \\
\hline & Polonez Cove & Chlamys Ledge & Late Oligocene (26.64 $\pm 1.43 \mathrm{Ma})$ & Polonez $(\text { c. } 26.7 \mathrm{Ma})^{e}$ \\
\hline & & Oberek Cliff & & \\
\hline & & Low Head & & \\
\hline & & Bayview & & \\
\hline & & Krakowiak Glacier & & \\
\hline
\end{tabular}

Note that the 'Mazurek Point Formation' (now Hennequin Formation) is omitted from the Oligocene stratigraphy; its age has been shown to be Eocene and unrelated geologically to the overlying formations of the Chopin Ridge Group (Pańczyk \& Nawrocki 2011, Smellie et al. 2021).

${ }^{a}$ Excludes the Sherratt Bay Formation (probable dolerite sill, part of the Cape Syrezol Group?).

${ }^{b}$ Probably a distal marine equivalent of the Cinder Spur Formation.

${ }^{c}$ New stratigraphical unit.

${ }^{d}$ Redefined stratigraphical unit.

${ }^{e}$ The Polonez Glaciation strictly only applies to the basal unit (Krakowiak Glacier Member), but conventional usage applies it to the entire formation.

upper Wesele Cove Formation, formed of agglomerates, conglomerates and sandstones (Birkenmajer 1982, 2001, fig. 43). In fact, the published stratigraphy is inverted and the Wesele Cove Formation, as defined by Birkenmajer (1982), mainly overlies the Polonez Cove
Formation directly across a sub-horizontal planar erosional unconformity, although in Oberek Cliff it is sandwiched between lavas of the Boy Point Formation (Figs 3, $5 \& 8$ ). In its form, attitude and extent, the basal unconformity resembles other planar erosional surfaces

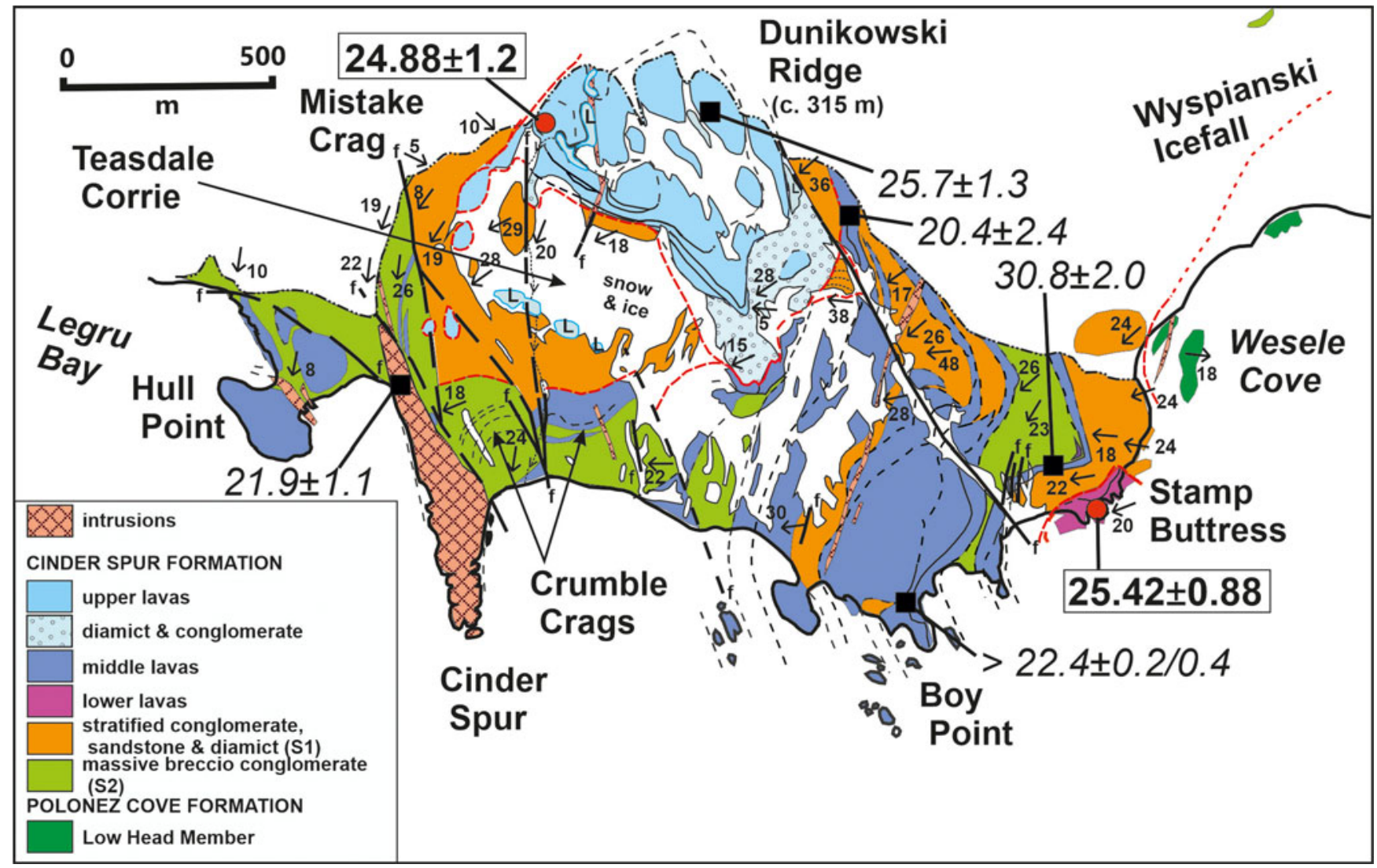

Fig. 9. Geological map of the Cinder Spur area, eastern King George Island. See Fig. 3 for explanation of additional symbols. 


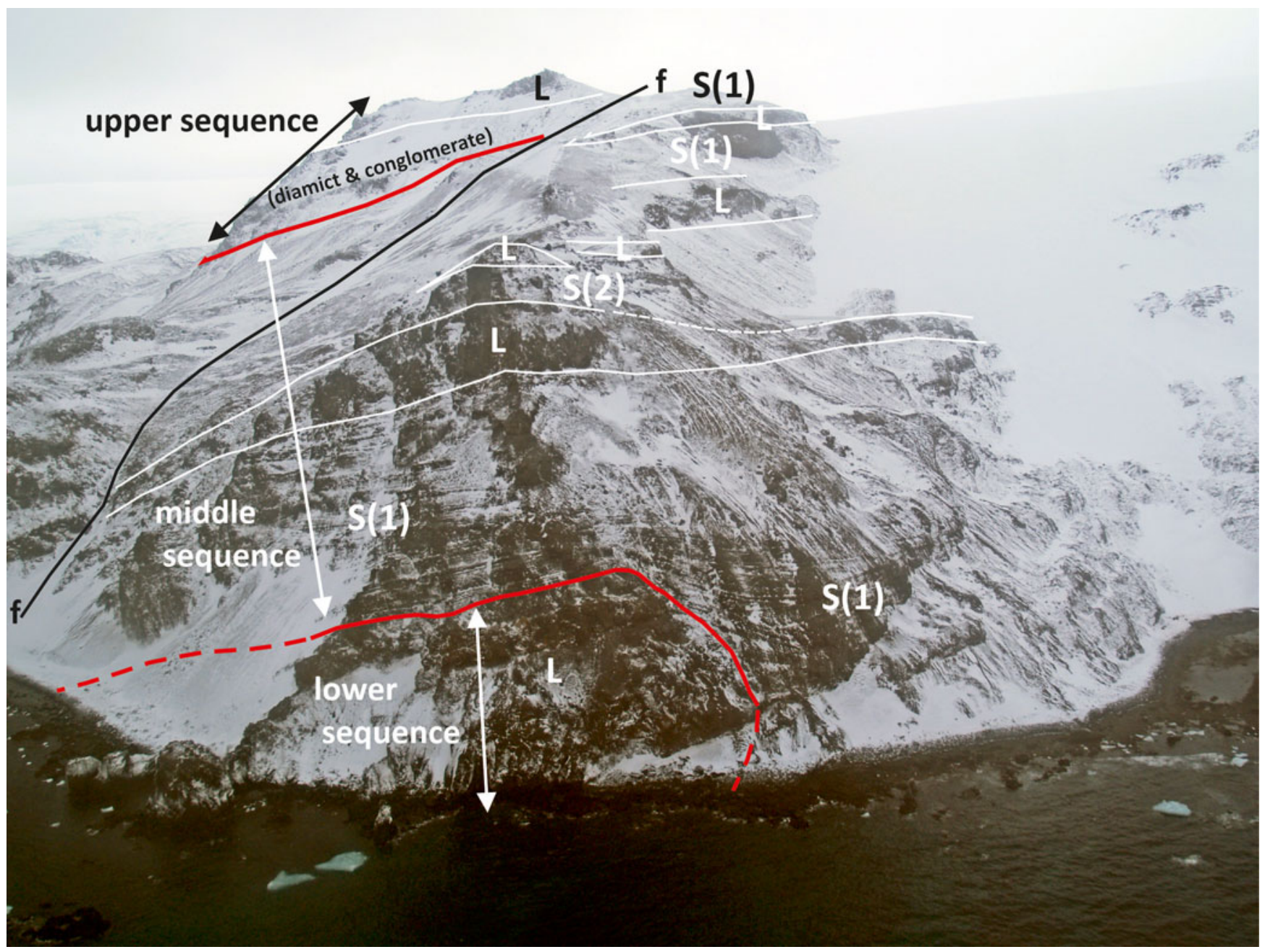

Fig. 10. View of Stamp Buttress, looking up Dunikowski Ridge, showing selected geological units (cf. Fig. 9). All of the rocks shown belong to the Cinder Spur Formation. Note how S(1), whilst occupying a channel cut in the lower lava sequence at right, is a conformable part of the sequence and not an outlier of the Wesele Cove Formation, as interpreted by Birkenmajer (1982) and which led to the lavas of the lower sequence being mapped incorrectly as part of the Boy Point Formation. Approximately $300 \mathrm{~m}$ of relief is shown. Red lines are prominent unconformities. $\mathrm{L}=$ lava; $\mathrm{S}(1), \mathrm{S}(2)=$ sedimentary rocks of type 1 and type 2 sequences, respectively; see text for further explanation.

observed within the Polonez Cove Formation, and they are present within the overlying Boy Point Formation too. Thus, the Wesele Cove Formation is essentially a sedimentary sequence contained within a thicker lava sequence. Its provenance is also andesitic-dacitic, similar to the associated lavas. Therefore, it is suggested that the Wesele Cove Formation is more appropriately reclassified as a member of the lava-dominated Boy Point Formation and it is here renamed the Wesele Cove Member (Table II).

The Boy Point Formation is dominated by andesite-dacite lavas (Birkenmajer 1982). Although an outcrop at Stamp Buttress (close to Boy Point; Fig. 9) was also assigned to the formation, it is compositionally and physically dissimilar (massive basaltic andesite lava and autoclastic breccia indistinguishable from lavas at
Boy Point nearby), and the original study by Birkenmajer (1982), which correlated unconformably overlying strata at Stamp Buttress with the Wesele Cove Formation, is incorrect. The supposed Wesele Cove Formation outcrop at Stamp Buttress is an integral part of the lava-dominated sequence that forms the Cinder Spur outcrop, and it is here assigned to the new Cinder Spur Formation (see below; Figs 9 \& 10). The exposed upper surface of the Boy Point Formation everywhere corresponds to the present-day erosion surface, but a steep cross-cutting unconformity can be inferred from the distribution of outcrops on the west side of Wesele Cove, where the Boy Point Formation and most of the Polonez Cove Formation are cut out (Fig. 9). The total thickness of the Boy Point Formation is difficult to measure, but it is probably $c .100-150 \mathrm{~m}$ 
Table III. Major oxide analyses of Oligocene lavas and intrusions, eastern King George Island.

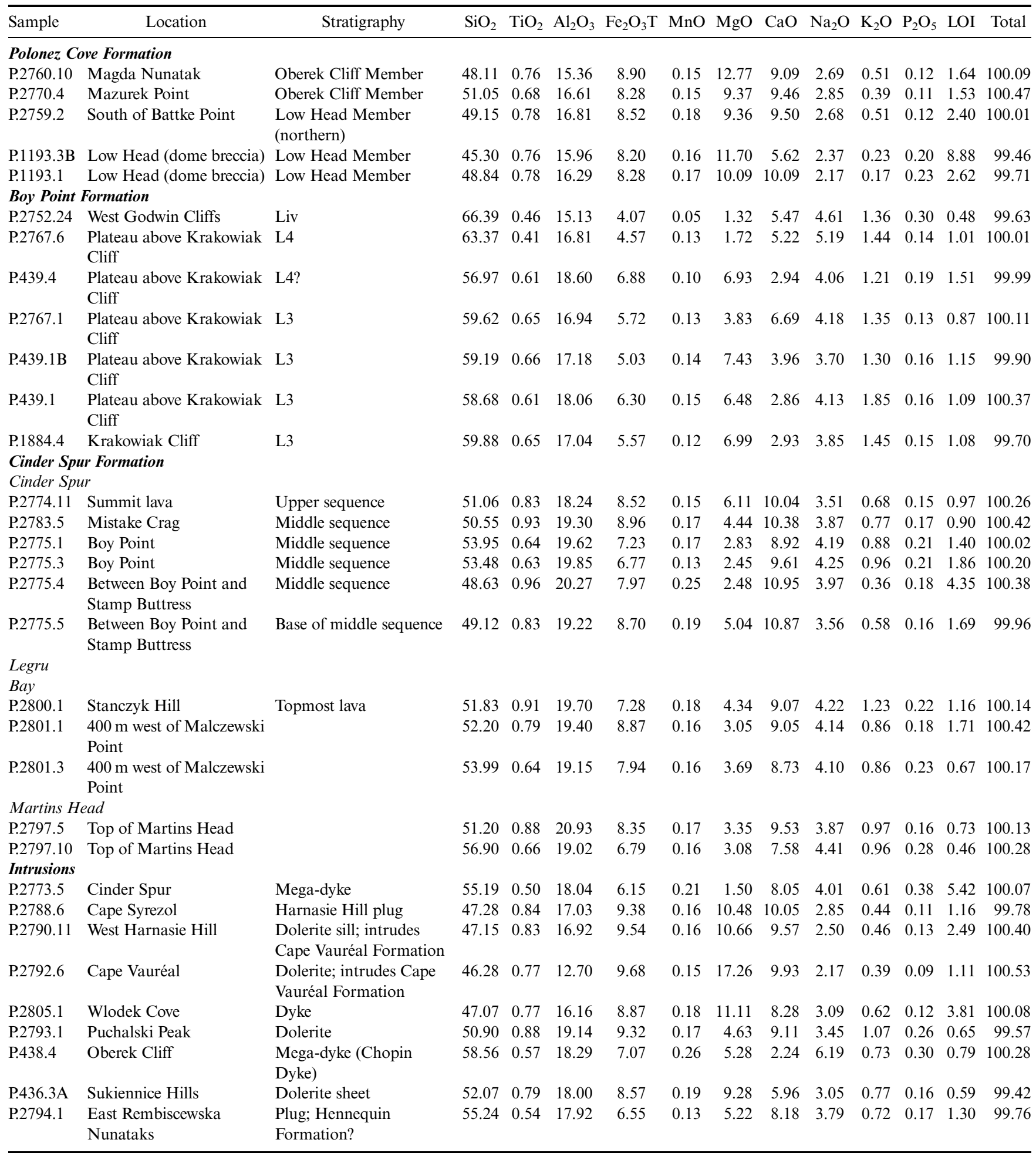

LOI $=$ loss on ignition.

(Birkenmajer 1982, estimated up to $120 \mathrm{~m}$ ). Despite the formation being absent at Boy Point, the name is embedded in the literature and is retained here. However, the type section is at Oberek Cliff (Figs $3 \& 8$ ).
Four lavas (L1-L4; Fig. 3) are present within the Boy Point Formation at Oberek Cliff. They are distinctive highly porphyritic andesites and dacites in which largely opaque oxide-altered hornblende phenocrysts are 
common and conspicuous (Table III). Elsewhere in the South Shetland Islands, amphibole is a rare phenocryst phase in lavas (Smellie et al. 1984). The lavas are brightly coloured (mainly pale green, pink, pale grey and khaki-brown), non-vesicular and characteristically pervasively fractured to brecciated (Fig. 7e). In Oberek Cliffs, the lowest stratum included in the formation comprises $c .25 \mathrm{~m}$ of purplish grey to pale green lava (L1; Fig. 8), which varies irregularly between coarse lava breccia and highly fractured but otherwise intact lava. Lava L2, pale pinkish grey in colour and composed predominantly of lava breccia, is only $8 \mathrm{~m}$ thick south of Chopin Dyke but thickens northwards to c. $>40 \mathrm{~m}$, across the fault occupied by the Chopin Dyke, before wedging out within the Wesele Cove Formation $c .400 \mathrm{~m}$ south of Battke Point. Lavas L3 and L4 are similar to L2 but with different colours.

Within the lavas above the Wesele Cove Member, granule conglomerate and sandstone (S4) occupy a prominent hollow c. $8 \mathrm{~m}$ deep overlying L2 in Krakowiak Crag. S4 is pale green-grey and mainly conglomeratic. It contains large chlamys fossil moulds, which are locally abundant. A sequence of polymict, green granule and pebble conglomerates (S5), c. $4 \mathrm{~m}$ thick, also overlies L2 on the south flank of Chopin Dyke. It is apparently unfossiliferous and comprises lensoid beds and pebble trails a few centimetres to $1.5 \mathrm{~m}$ thick, which are crudely interstratified with rare thin sandstone lenses, with some channelized trough cross-stratification and (?)tabular cross-bedded sets. The stratigraphical position of S5 is uncertain. It overlies L2 similar to S4, but it is also overlain by L4 (L3 is absent south of Chopin Dyke), similar to S6 north of Chopin Dyke. Lithologically, S5 is more like S4. The characteristics of S6 are very uncertain as it is preserved solely as a felsenmeer of fissile platy debris composed of feldspathic sandstone and rare pebble conglomerate. It crops out on the undulating plateau above Krakowiak Crag.

A hitherto-unrecognized likely internal erosion surface truncates L2, S4 and S1 (S1 described below). It is planar and sub-horizontal and best seen in the east-facing Oberek Cliffs north of Chopin Dyke (Fig. 8). The surface is overlain by lavas L3 and L4. Lava L3, pale green to brown in colour, is intruded by and intimately intermixed with massive, mainly pale grey polymict diamictite, which appears to have originally covered parts of the underlying erosion surface. The youngest unit in the formation is pale grey to pink lava (L4). Its basal surface is uneven on a large scale, draping L3 and probably S6.

Wesele Cove Member: The lavas of the Boy Point Formation are interbedded with volcanic-sourced sediments. The most prominent deposit is identified here as the Wesele Cove Member, which forms a sequence $>80 \mathrm{~m}$ thick (see also Birkenmajer 1982). It overlies lava
L1 in Oberek Cliffs (Fig. 8), and it is dominated by distinctive pale grey or pale khaki-coloured feldspathic sandstones. The sandstones have a gently north-eastdipping homoclinal stratification that oversteps the basal unconformity with the Polonez Cove Formation. The Wesele Cove Member has been divided informally into three subunits (S1-S3) separated by planar, slightly erosive surfaces (Fig. 8). The separating surfaces are only obvious, as shallow notches, in Oberek Cliff on both sides of Chopin Dyke. Although some of the subunits presumably extend further north into Krakowiak Crag, they have not been mapped owing to the poor exposures and lithological similarities between the sediment packages. In addition, correlation of specific subunits across Chopin Dyke (which occupies a fault) is uncertain. The upper contact is a gently north-dipping, planar to locally very uneven surface overlain by lava L2, which cuts out the highest sedimentary package. The surface may be erosional or lava L2 may have sunk in unconsolidated sandstones of the Wesele Cove Member (Fig. 8). The member is described from the base up in Chopin Ridge.

The basal strata of the Wesele Cove Member, locally overlying L1 in southern Oberek Cliff, comprise up to $10 \mathrm{~m}$ of green (?)monomict gravelly conglomerate and laminated coarse sandstone, some with isolated outsize lava blocks, and there are lenses of blocky volcanic breccia. These beds are overstepped northwards by c. $25 \mathrm{~m}$ of very thick (up to $10 \mathrm{~m}$ ) beds of massive, monomict lava breccia, alternating with thinner (few metres) units of pale green, thinly laminated sandstone. This sequence (S1) fines upward, from basal breccias, through finer breccias, up into sandstones. South of Chopin Dyke, S2 and S3 consist of a total of c. $28 \mathrm{~m}$ of white feldspathic sandstone and minor gravelly sandstone. Beds are typically hard to distinguish. The sequence also contains pebbly conglomerate and coarse breccio-conglomerate in beds up to $8 \mathrm{~m}$ thick, which become thinner northwards.

Other outcrops of the Boy Point Formation: Lavas of the Boy Point Formation also crop out at Linton Knoll (Fig. 3). At least five different lavas are present $(\mathrm{Li}-\mathrm{Lv})$, ranging from 2 to $20 \mathrm{~m}$ thick with thinner lavas towards the top; they are thinner than lavas in the outcrop above Krakowiak Crag but otherwise indistinguishable in appearance. The lavas are interbedded with a poorly seen, thin $(\leq 6 \mathrm{~m})$ deposit of pebble and cobble conglomerate and matrix-rich volcanic breccio-conglomerate (Sii). A thin wedge of pale grey feldspathic coarse sandstone and granule to pebble conglomerate also crops out in situ and as morainic debris at Godwin Cliff, directly beneath the lava sequence just described (Fig. 3). It may either be an outlying outcrop of the Wesele Cove Member or it is a sediment wedge above that member within the lava sequence, similar to sediment subunits S4 and S5 (described above). 


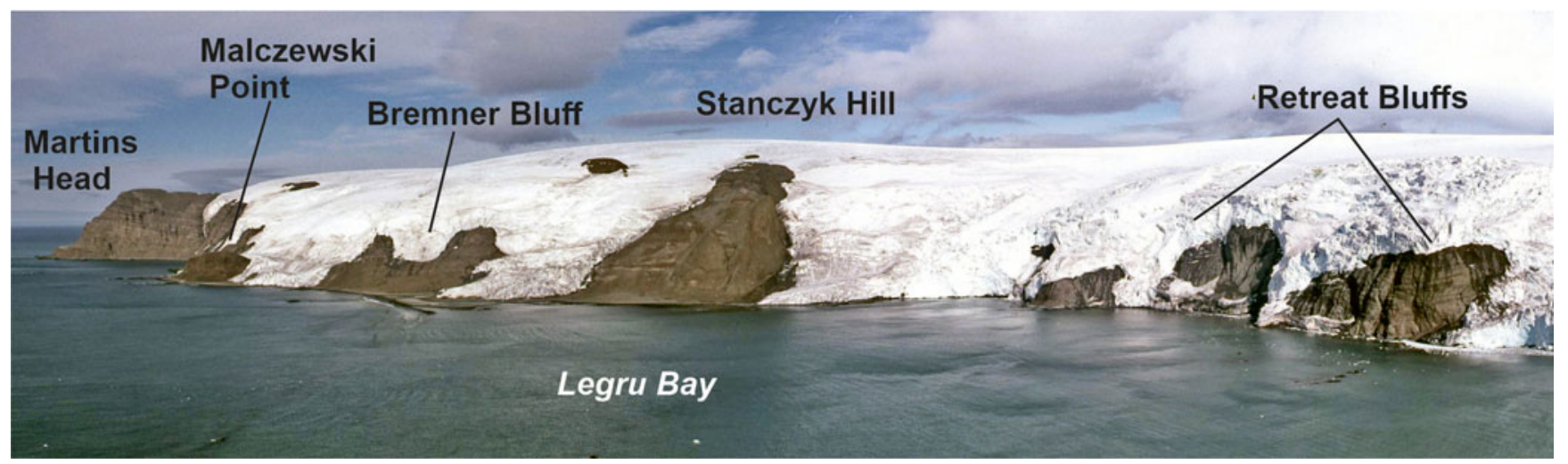

Fig. 11. View of outcrops of the Cinder Spur Formation on the west side of Legru Bay. The varied dip orientations seen in the outcrops suggest that they were formed in more than one volcanic edifice; that responsible for Martins Head, in which strata dip to the right (approximately to the north-west), must have been situated in Bransfield Strait but has been considerably eroded.

Although the outcrop of the Boy Point Formation is apparently confined to the Lions Rump-Low HeadLinton Knoll area, rare clasts of lithologically identical hornblende-phyric andesite occur in sedimentary rocks at Martins Head and Harnasie Hill, in outcrops assigned to the Cinder Spur Formation (see below). The presence of the clasts may suggest that either the Boy Point Formation crops out more widely and its lavas were reworked into the younger formation or else hornblende andesite lavas may also have erupted within the Cinder Spur Formation but are not currently exposed.

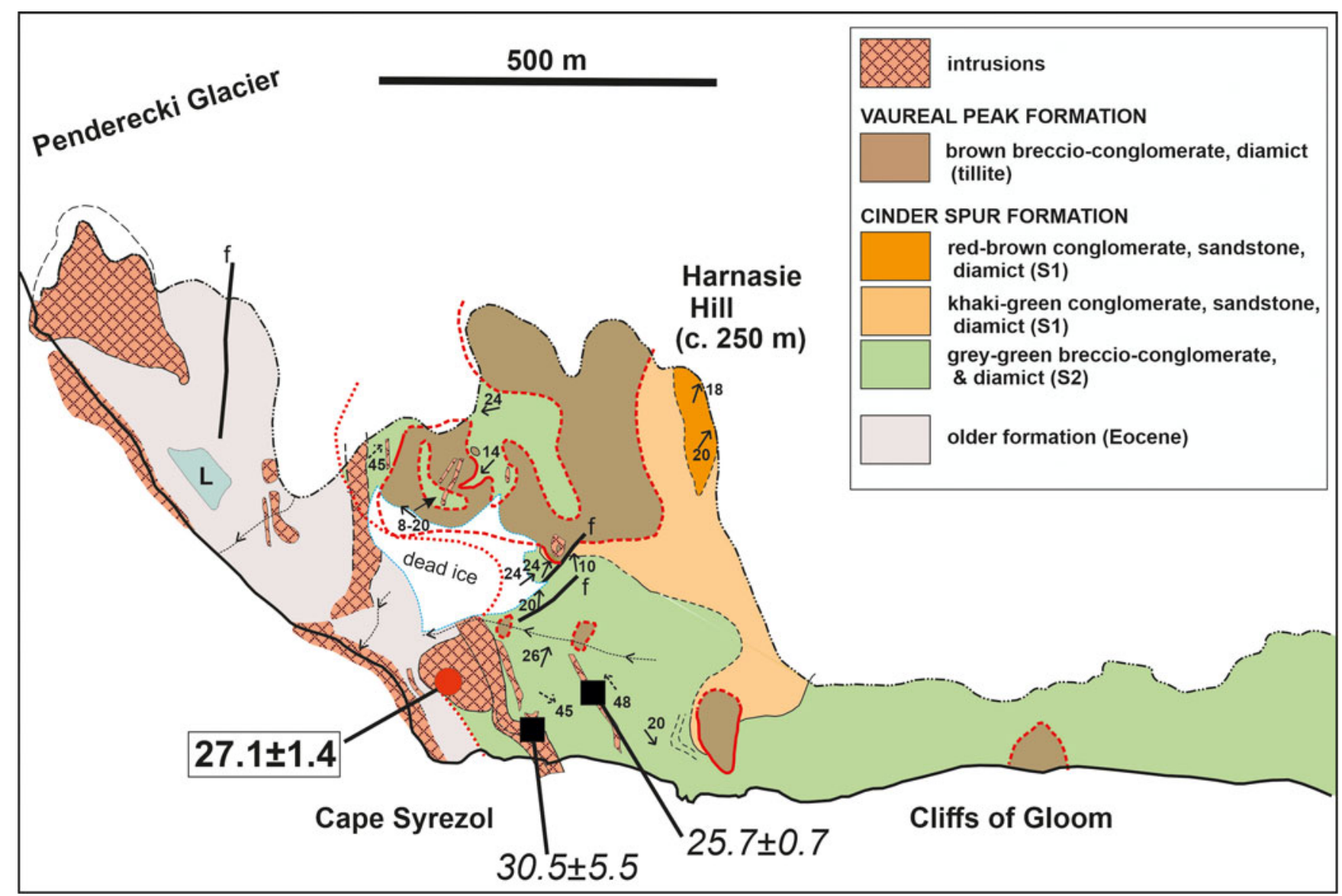

Fig. 12. Geological map of the Harnasie Hill area. See Fig. 3 for explanation of additional symbols. 


\section{Cinder Spur Formation (new stratigraphical unit)}

The Cinder Spur Formation is the most extensive Oligocene stratigraphical unit on eastern King George Island. The type locality is at Cinder Spur, where the range of lithofacies and their relationships are best exposed (Fig. 9). Other outcrops occur on the west side of Legru Bay, at Retreat Bluffs, Stanczyk Hill, Martins Head and Harnasie Hill (Fig. 11). The only published maps of Cinder Spur are on a very small scale (Barton 1965, Birkenmajer 1982). Birkenmajer (1982) divided the sequence into five parts: a basal basalt lava sequence (Boy Point Formation, at its type locality; reassigned here to the Cinder Spur Formation), unconformably overlain by agglomerates, conglomerates and sandstones of the Wesele Cove Formation, itself unconformably overlain by lavas of the Dunikowski Ridge Formation. To the west, across a fault, the Dunikowski Ridge Formation (lava, conglomerate, agglomerate) was overlain by the Harnassie Hill Formation (agglomerate and tuff of a basaltic cinder cone), itself overlain by the Martins Head Formation (lava, agglomerate). Unfortunately, many of the published details of the geology of Cinder Spur are incorrect (e.g. see Figs $9 \& 10$ ).

The Cinder Spur Formation is composed of alternating lavas and sedimentary rocks (Fig. 9). Its base is unexposed, but at Harnasie Hill it overlies Eocene strata of the Cape Vauréal Formation, although the nature of the contact is uncertain (Fig. 12; Smellie et al. 2021). The top is mainly the present-day erosion surface except where it is erosively overlain by the Vauréal Peak Formation, of uncertain age (see later). The relationship with the Boy Point Formation is unknown as no contacts are exposed, but our interpretation of the outcrops on the west side of Wesele Cove suggest a strong erosional unconformity is present that is probably responsible for restricting the western outcrop extent of the Boy Point Formation. Because of faulting and large ice-covered gaps in exposure, the total thickness of the Cinder Spur Formation is unknown, but it must exceed $500 \mathrm{~m}$ (see also Birkenmajer 1982).

At the type locality at Cinder Spur, the succession is formed of at least three unconformity-bounded sequences, as follows: 1) a lower sequence formed of two lavas, which Birkenmajer (1982) assigned to his Boy Point Formation (reassigned here to the Cinder Spur Formation), 2) a middle sequence at least $200-250 \mathrm{~m}$ thick, composed of alternating lavas and lithologically variable volcaniclastic sedimentary rocks and 3) an upper, lava-dominated sequence. The sequences dip at low to moderate angles $\left(10-38^{\circ}\right.$, typically $\left.20-25^{\circ}\right)$ to the west-south-west, swinging round to more southerly dips in the western outcrops. Intraformational unconformities were observed rarely within the middle sequence but are probably quite common (e.g. that mapped at the base of the upper sedimentary sequence shown in Fig. 9). Fossils are absent, although possible plant stem impressions were observed on a bedding plane at a single locality. The variable dip orientations at the different localities further west on King George Island (Figs 12-14) suggest that the sequences were erupted from more than one volcanic centre, and that responsible for the sequence at Martins Head was formerly situated in Bransfield Strait (Fig. 11).

Lavas in the Cinder Spur Formation are conspicuously feldspar-pyroxene-phyric basalts and silica-poor basaltic andesites (Table III). Many contain minor, mainly iron oxide-altered amphibole phenocrysts. Olive green and red-brown amphibole crystals are also ubiquitous and conspicuous in the associated sedimentary strata, in lava clasts and as phenoclasts. The abundance of amphibole in the sedimentary rocks suggests that hornblende andesite or dacite lavas crop out in situ within the Cinder Spur Formation rather than the debris being derived solely by erosion and reworking of the Boy Point Formation. Thus, the lavas in both formations may share a similar petrogenesis. They consist of massive centres encased in autobreccia characteristic of subaerial 'a'à effusion. Fresh clinopyroxene is particularly characteristic and conspicuous, occurring as abundant, often large phenocrysts (and phenoclasts in the interbedded sediments) up to several millimetres in length. Brown juvenile clast-rich muddy diamictites (slurry-flow deposits) occur directly beneath many of the individual lavas in the type section. Lavas at Cinder Spur are typically $c .10 \mathrm{~m}$ thick, rising to $c .25 \mathrm{~m}$. Elsewhere, lava thicknesses are more variable, with massive portions ranging from c. $5 \mathrm{~m}$ to $30 \mathrm{~m}$ encased in relatively thin (few metres), pale grey to pink, scoriaceous autobreccia.

Sedimentary sequences interfinger with lavas throughout the Cinder Spur Formation. Two distinctive types of sedimentary sequences are present and are distinguished by stratification, colour and the dominant lithofacies. Type 1, which is less common except at Cinder Spur, consists of well-stratified, relatively thinbedded, multi-coloured (mainly pale khaki-grey and red) fine conglomerate, gravelly sandstone and diamictite (Fig. 7f). Type 2 comprises poorly stratified, thickbedded, mainly grey green coarse and fine conglomerates and breccio-conglomerates (Fig. 7g). The commonest and most widespread sedimentary lithofacies in the type 1 sedimentary sequences are pale-coloured, khaki-grey, green and red gravelly sandstones, granule and pebble conglomerates and purplish-brown pebbly mudstone diamictites. Although the colours often appear to be stratigraphically confined, they are also commonly vagrant and follow fractures that cross the local sequence irregularly. The lithologies are planar bedded and remarkably continuous on an exposure scale, most beds being restricted only by erosive channels. Channels 


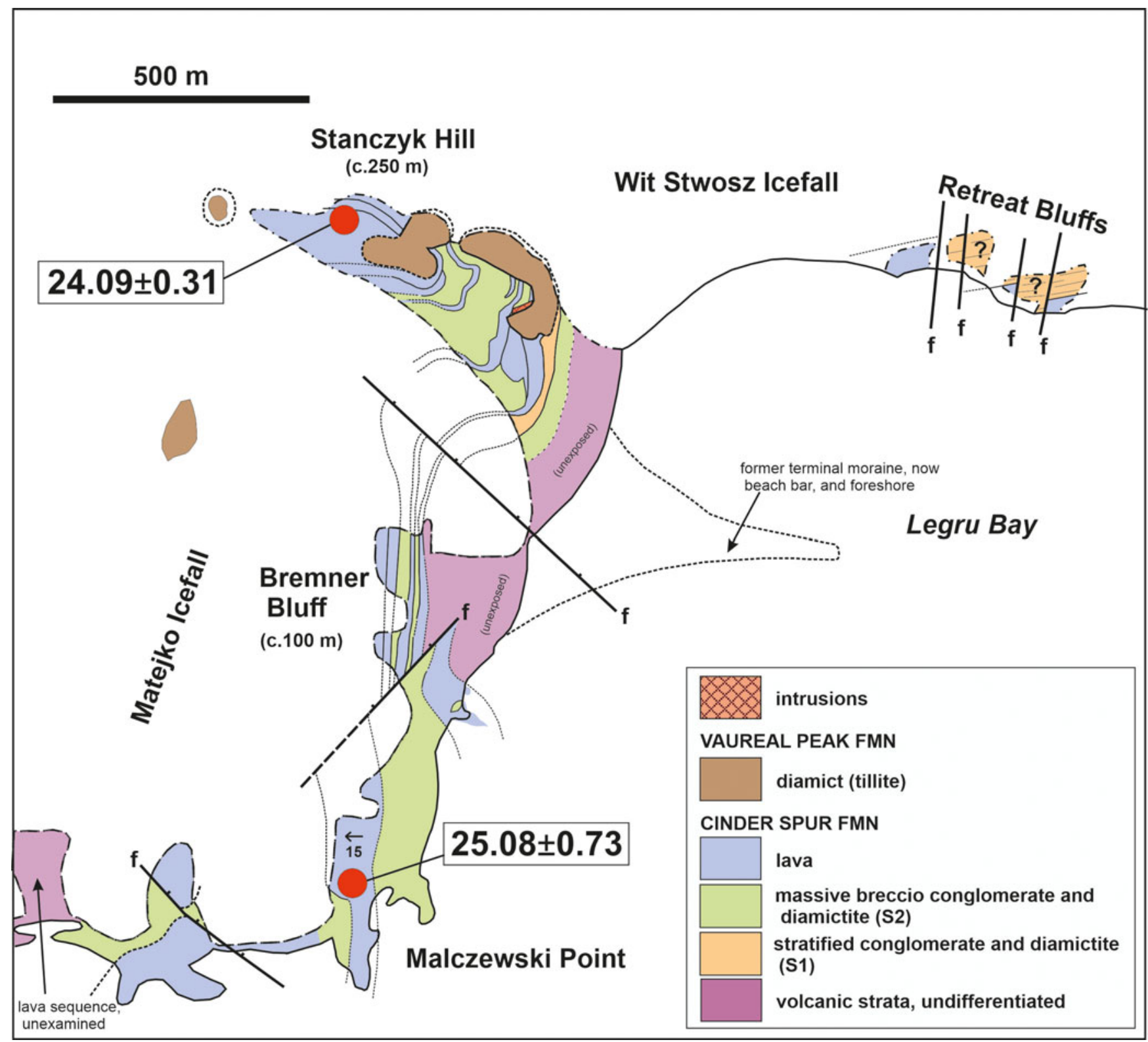

Fig. 13. Geological map of the Stanczyk Hill-Malczewski Point area. See Fig. 3 for explanation of additional symbols.

are conspicuous and characteristic, usually several tens of metres wide and a few metres to sometimes tens of metres deep. Pale khaki-coloured juvenile lava lapilli with a wide range of sizes are common. However, the clast population is polymict, formed of locally derived feldsparclinopyroxene-phyric lavas, with or without hornblende phenocrysts. Most beds are massive.

The more common type 2 sedimentary sequences are dominated by grey green, poorly sorted granule to small-pebble conglomerates, breccio-conglomerates and diamictites with abundant sandstone matrix and numerous dispersed sub-rounded-angular pebbles to boulders. As in the type 1 deposits, many clasts $\leq 2 \mathrm{~cm}$ are essentially monomict, formed of yellow juvenile lapilli, whereas clasts $>2 \mathrm{~cm}$ are polymict, dominated by locally derived lavas. Bedding is often difficult to discern but is planar and mainly up to $1 \mathrm{~m}$ thick. Most beds are massive. Some beds of coarse breccio-conglomerate are up to $10 \mathrm{~m}$ thick, with abundant fine sandstone or mudstone matrix; many display a strong bed-parallel fissile jointing. A particularly thick deposit of diamictite and conglomerate underlies the upper lava sequence at Cinder Spur, and it occupies a channel at least several tens of metres deep cut in the middle sequence at that locality.

As at Cinder Spur, lavas are subordinate or sub-equal to sedimentary strata in outcrops at Retreat Bluffs, Stanczyk 


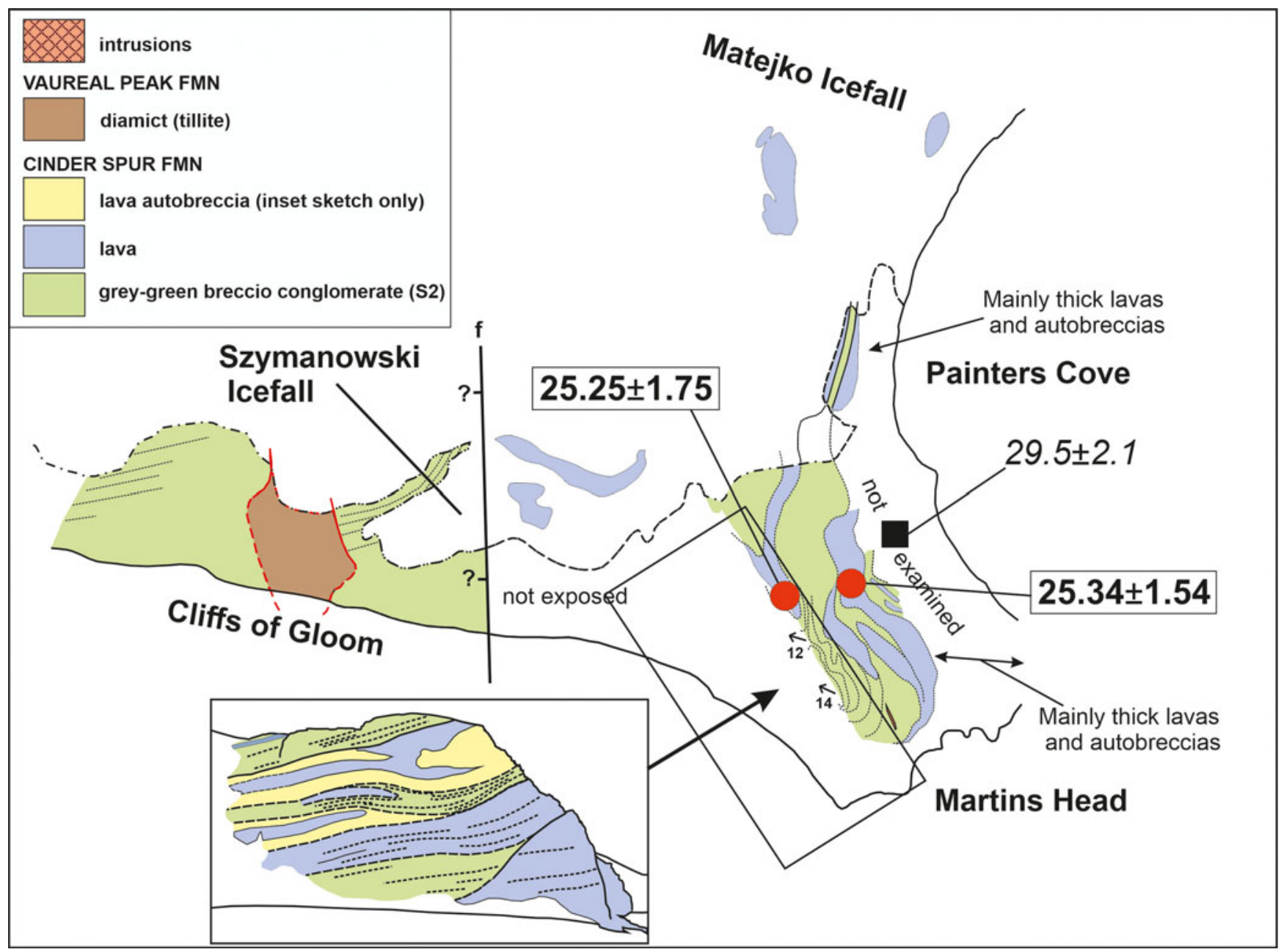

Fig. 14. Geological map of Martins Head. See Fig. 3 for explanation of additional symbols. The geological details shown in the Cliffs of Gloom and in the inset are based on binocular observations.

Hill and Bremner Bluff, but they are dominant at Martins Head and Malczewski Point (Figs 13 \& 14). By contrast, the Harnasie Hill outcrop is entirely sedimentary (Fig. 12). The exposed sequences are c. $250 \mathrm{~m}$ thick at each of the three main outcrops (Stanczyk Hill, Martins Head, Harnasie Hill). The bedding dips generally to the west or south-west, but it is more variable at Harnasie Hill. Interbedded sedimentary sequences individually up to $25 \mathrm{~m}$ in thickness are common in the summit succession at Martins Head and at Malczewski Point and Stanczyk Hill. They are mainly type 2 sequences of khaki to greenish-coloured, thick-bedded ( $>1-2 \mathrm{~m}$, up to $6 \mathrm{~m}$ ) sandy coarse breccio-conglomerates or polymict volcanic breccias, in very thick (up to $>14 \mathrm{~m}$ ) massive beds, together with brown-coloured muddy diamictites. In contrast, a $9 \mathrm{~m}$-thick type 1 sequence of planarbedded, multi-coloured muddy fine diamictites, less common pebbly conglomerates and coarse sandstones with large-scale channel scars crops out near the base of Stanczyk Hill, and binocular observations suggest that similar rocks are present in inaccessible Retreat Bluffs (Fig. 13). Type 1 and type 2 sedimentary sequences are also present at Harnasie Hill, where the thickest accumulation of type 2 sequence is present $(\geq 200 \mathrm{~m}$ thick; Fig. 12). It is the type area for the Harnasie Hill Formation of Birkenmajer (1982, p. 45), described as 'Basaltic lapilli tuff and breccia ... alternating with agglomerate, tuff-sandstone and tuff-shale, ... porphyritic basalt lava flow and lava-agglomerate-conglomerate intercalations'. The whole sequence was interpreted as a basaltic cinder cone deposit. However, despite the presence of yellow to pale green (?)juvenile granule-size lapilli, which may be abundant locally, the deposits are overwhelmingly sedimentary. The strata at each locality are polymict except at Cape Syrezol, where the basal $25 \mathrm{~m}$ of the seaward-facing cliffs are formed by massive to crudely planar stratified, dark green, fine vitroclastic deposits, at least some of which are probably pyroclastic (coarse tuffs). Whilst the clasts characteristically appear to be locally derived lavas of the Cinder Spur Formation, 


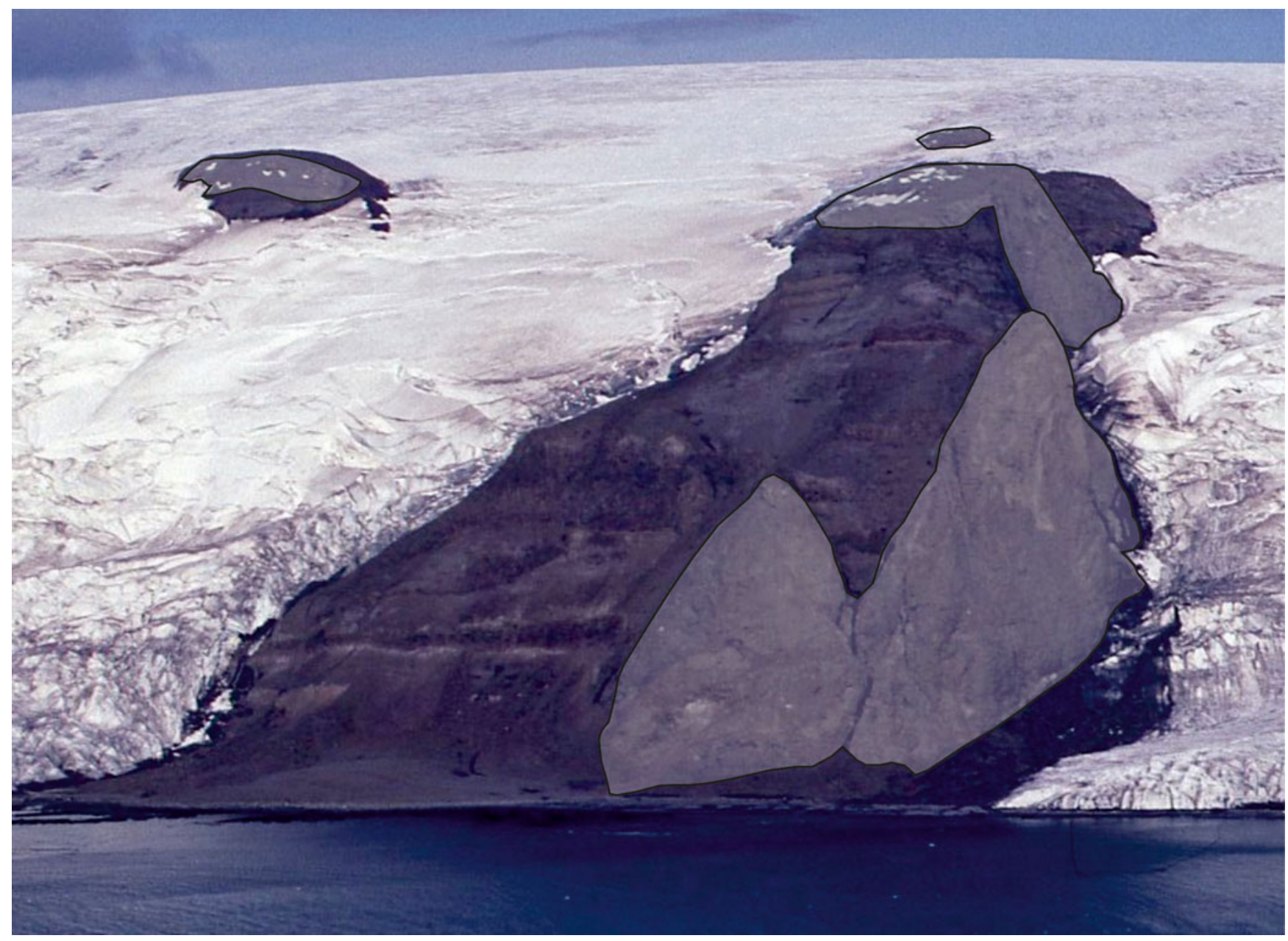

Fig. 15. View of Stanczyk Hill from Cinder Spur, showing outcrops of Vauréal Peak Formation diamict (grey) draped over lavas and clastic rocks of the Cinder Spur Formation. The diamict drapes an eroded surface cut c. $250 \mathrm{~m}$ down into the volcanic sequence, which is being exhumed as the diamict is eroded away.

a large block a few metres in diameter, composed of pale purple fissile lava with prismatic amphibole, was observed locally; the clast has a remarkable resemblance to lavas in the Boy Point Formation, and a similar hornblende andesite cobble was observed in muddy diamictite at Martins Head. The Harnasie Hill sedimentary strata are in faulted contact with lavas just west of Martins Head (Fig. 14).

Lastly, Conglomerate Nunatak (Fig. 1) was mapped previously as green basaltic conglomerate of the Polonez Cove Formation (Low Head Member), probably on the basis of the presence of blocks of fossiliferous Polonez Cove Formation lying nearby (not observed during our study; cf. Birkenmajer 1982; see also Tokarski et al. 1981). The conglomerate was said to be overlain by tuff, agglomerate and lava of the Boy Point Formation. However, the outcrop is formed entirely of unfossiliferous, clast-supported breccio-conglomerate and conglomerate. The deposits are khaki or grey-coloured, rich in pale grey juvenile clasts and crudely stratified in the south-west exposures, changing south-eastwards into massive green strata dominated by basalt lava clasts. They are pervasively and prominently red-stained in places. The closest overall resemblance is to sedimentary strata in the Cinder Spur Formation, possibly both type 1 (south-west) and type 2 (south-east) sequences, with which the outcrop is provisionally correlated.

\section{Vauréal Peak Formation}

The study area contains the type section for the Vauréal Peak Formation (also informally called the Vauréal Peak tillite; Birkenmajer 1982) at Vauréal Peak (Fig. 4). Its age is unknown but inferred to be $c .25 \mathrm{Ma}$ (Birkenmajer et al. 1989). The formation has a minimum thickness of $c .70 \mathrm{~m}$. It is formed of a khaki-brown to brownish-green massive coarse diamictite dominated by brown siltstone-fine sandstone matrix $(30-70 \%)$ in which are dispersed angular-subangular (rarely well-rounded), 
coarse sand to cobble-sized polymict lava clasts. Similar to sedimentary rocks in the underlying Cinder Spur Formation, well-formed phenoclasts of clinopyroxene are common, plus lesser amphibole, and practically all of the lithic clasts are of feldspar-pyroxene-phyric basalt lavas with minor hornblende andesite or dacite. Large blocks of sandstone and granule conglomerate several metres in length similar to type 2 sequence rocks of the Cinder Spur Formation were also observed in basal diamictite at one locality (the so-called 'fossil ice wedge' locality described by Birkenmajer 1982, figs 22 \& 23). $\mathrm{K}-\mathrm{Ar}$ whole-rock isotopic dating of a lava block in the outcrop near Vauréal Peak yielded an Eocene age (47.0 $\pm 1.1 \mathrm{Ma}$; Birkenmajer et al. 1989), indicating that some Eocene outcrops also contributed clasts to the Vauréal Peak Formation. A small proportion of outsize blocks is also present, up to $2.3 \mathrm{~m}$ in diameter (generally $<50 \mathrm{~cm}$ ), but with at least one likely megaclast $3-4 \mathrm{~m}$ across, composed of Cinder Spur Formation lava breccia (Smellie et al. 2021). Several of the larger blocks are fractured, and fine matrix from the diamictite infills the fractures and extends as thin veinlets a short distance into the surrounding diamictite (sketched in Birkenmajer 1982, fig. 22). Stratification occurs very rarely within the Puchalski Peak outcrop (Fig. 4), comprising faintly (often wispy) stratified gravelly conglomerate, pebble trails and wavy (disturbed) planar laminated sandstone. The stratification is typically $10-20 \mathrm{~cm}$ thick and extends laterally only a few metres before fading out into massive diamictite. This is not the large-scale (?)stratification-like 'plastic folds-undulations' [sic] alluded to by Birkenmajer (1982, fig. 14), which were not observed by us.

The Vauréal Peak Formation occupies a V-shaped palaeovalley with steep to sub-vertical margins in the type locality outcrop between Vauréal Peak and Cape Vauréal (Fig. 4). The margins are well exposed at two localities, and features interpreted as a fossil ice wedge at one were described by Birkenmajer (1982). At the latter, lava of the adjacent outcrop of the Eocene Hennequin Formation is brecciated and contains scarce admixed fragments of possible Cape Vauréal Formation lava (also Eocene) and a few of dolerite (for a description of the Eocene stratigraphy, see Smellie et al. 2021). The breccia grades laterally downwards through jigsaw-fractured lava into massive Hennequin Formation lava and up into Vauréal Peak Formation diamictite. Birkenmajer (1982) also recorded glacial striations on a surface of Eocene (Hennequin Formation) lava beneath the lava breccia just described, but they were not observed by us.

At Puchalski Peak, the Cape Vauréal Formation unconformably drapes a narrow west-south-westtrending ridge composed of steep-dipping pyroxenefeldspar-phyric lavas (correlated with the Eocene Carruthers Cliff Formation of Vauréal Peak; Smellie et al. 2021) and dolerite (Fig. 4). Both the lavas and dolerite are heavily fractured, with the intensity of fracturing increasing close to the contact with the Cape Vauréal Formation. At Stanczyk Hill, Cape Syrezol summit and west of Martins Head, diamictite forms a spectacular exposure draped on and over the Cinder Spur Formation (Figs 13-15). The basal erosional surface cuts down at least $250 \mathrm{~m}$, and diamictite adheres to almost vertical rock faces at three places in the Cliffs of Gloom (Fig. 7h).

Outcrops of the Vauréal Peak Formation at Harnasie Hill (Fig. 12) rest on an uneven undulating palaeotopography developed on the Cinder Spur Formation. Additionally, at one locality, sedimentary strata in the underlying Cinder Spur Formation are very disturbed, with bedding dips varying irregularly from $8^{\circ}$ to $20^{\circ}$ in a zone a few metres wide close to the Vauréal Peak Formation.

\section{Intrusions}

Hypabyssal intrusions, including dykes, sills and irregular sheets of basalt and dolerite, are generally minor in the areas studied except at Harnasie Hill, where they are common and conspicuous, although mainly intruding Eocene strata (Fig. 12). The largest individual examples are 'mega-dykes' at Cinder Spur and the Chopin Dyke north of Low Head (130 and $75 \mathrm{~m}$ wide, respectively); a plug-like mass $c .125 \mathrm{~m}$ in diameter at Cape Syrezol; and a thick (several tens of metres) northerly inclined sheet at Sukiennice Hills (Figs 3, 9 \& 12). The latter was interpreted as a sequence of dipping thin lavas by Birkenmajer (1994), and together with adjacent poorly exposed volcaniclastic rocks, they were combined in his Sukiennice Hills Formation, undated but with an estimated age speculatively thought to be close to the Eocene-Oligocene boundary (but see Smellie et al. 2021). Although no contacts are exposed, the relatively coarse dolerite textures and presence of pervasive crude 'layer-like' structures dipping at $22-44^{\circ}$ to the north, contrasting with the shallower (mainly $c .20^{\circ}$ ) southerly dips of the adjacent sedimentary strata, are distinctive features that are also seen in dolerite sills elsewhere in the South Shetland Islands (e.g. at Hall Peninsula (Snow Island), Williams Point (Livingston Island), Duff Point (northern Greenwich Island) and Fort William (Robert Island; Smellie et al. 1984, figs 21 \& 22). Additionally, although the Sherratt Bay Formation at Cape Melville (Fig. 1) is currently interpreted as a 'terrestrial plateau-basalt sheet' $>60 \mathrm{~m}$ thick, and it is included in the Moby Dick Group (Table I; Birkenmajer 1987), it is also doleritic, with pervasive columnar jointing and coarse (1-2 cm diameter) nodular textures on weathered surfaces caused by zeolite alteration (cf. Birkenmajer 1987, and unpublished information of JLS). A thick dyke on the north flank of the eastern tip of Cape 
Melville intrudes the Cape Melville Formation and appears to be continuous with the underlying Sherratt Bay Formation (observation of AT). The nodular surface was interpreted as a hydrothermal and weathering feature created prior to deposition of the Destruction Bay Formation, implying an age older than the Destruction Bay Formation (Birkenmajer et al. 1988b). However, similar distinctive nodular textures occur in several of the dolerites listed above and were caused by deuteric alteration rather than weathering. The sum of the features we have described, particularly if the connection with a dyke is verified, is more characteristic of an intrusion (mainly a sill), albeit possibly a large one, or more than one, with a possible outcrop extending across Destruction Bay to Trowbridge Island (Fig. 1). The sill has not been accurately dated, but it yielded a poor K-Ar age of $>18 \mathrm{Ma}$ (Birkenmajer et al. 1985). Finally, the columnar-jointed oval outcrop at Low Head, regarded as a sub-volcanic plug by Birkenmajer (1982; see also Smellie et al. 1984), is not an intrusion. It is a small lava dome with associated carapace breccia extruded in a submarine setting coeval with deposition of the Oligocene Polonez Cove Formation, in which it is grouped within the Low Head Member (subunit L1 of Troedson \& Smellie 2002; see Smellie et al. 1998).

\section{Summary of main stratigraphical results}

As a result of our investigation, significant changes that we propose to the lithostratigraphy of eastern King George Island are summarized as follows (cf. Tables I \& II):

1) The Magda Nunatak Complex, formerly thought to be Eocene in age, is reassigned to the Oligocene Polonez Cove Formation, as originally suggested by Tokarski et al. (1981).

2) The Wesele Cove Formation is shown to underlie the Boy Point Formation, a reverse of the published stratigraphy. Moreover, it is now known to be sandwiched between andesite-dacite lavas of the Boy Point Formation; as a result, the Wesele Cove Formation is reclassified here as a member of the Boy Point Formation.

3) The Harnasie Hill Formation, previously interpreted as a discrete stratum formed of agglomerate of a 'cinder cone' that intervenes between the Dunikowski Ridge and Martins Head formations, is neither formed of agglomerate nor does it form a single mappable datum. It occurs as multiple packages of sedimentary rock interbedded throughout the volcanic sequence. Moreover, the overlying and underlying Martins Head and Dunikowski Ridge formations are lithologically indistinguishable. Thus, the three formations are combined into a single unified volcano-sedimentary unit here named the Cinder Spur Formation.

4) The Vauréal Peak Formation, a glacial diamict (tillite), is removed from the Legru Bay Group. It was previously linked stratigraphically with the underlying Martins Head, Harnasie Hill and Dunikowski Ridge volcanic formations. However, there is no obvious unifying characteristic that might be used to group together the different formations in the Legru Bay Group. Moreover, there is evidence for a substantial age gap between the Vauréal Peak Formation and the underlying units.

\section{Chronology}

\section{Results of previous studies}

Palaeontology: The Polonez Cove Formation (including the outlying sequence at Magda Nunatak) is highly fossiliferous but, because of recycling of fossils, it has proved hard to derive an unambiguous palaeontological age. Coccoliths, bivalves, gastropods, foraminifera, worms, echinoderms, bryozoans, coral, brachiopods, a diatom genus, algae and palynomorphs including dinoflagellates, spores, gymnosperm and angiosperm pollen, as well as stromatolites have all been described (see complete listing and references in Supplemental Information S3 \& S4). The Low Head Member is the most diverse unit of the formation, but all of the members are fossiliferous to a variable extent. However, coccoliths are the only age-diagnostic fossils. They indicate an upper Early Oligocene to Late Oligocene age, usually quoted as $c$. 33-32 Ma (e.g. Gazdzicki \& Pugaczewska 1984, Gaździcka \& Gaździcki 1985, Birkenmajer \& Gaździcki 1986, Birkenmajer et al. 1988a).

Isotopic dating studies: An age for the Polonez Cove Formation (Low Head Member) slightly younger than that suggested by the palaeontology was obtained based on ${ }^{87} \mathrm{Sr} /{ }^{86} \mathrm{Sr}$ isotopic analyses (i.e. c. $29-28 \mathrm{Ma}$; Dingle et al. 1997, Dingle \& Lavelle 1998). Other ${ }^{87} \mathrm{Sr} /{ }^{86} \mathrm{Sr}$ ages of c. 32-30 Ma have also been reported for the Krakowiak Glacier Member, as well as $27.0 \pm 0.3 \mathrm{Ma}$ for the Chlamys Ledge Member, but the details are unpublished (K. Krajewski, cited by Warny et al. 2019). However, widespread alteration of the shelly material in the Polonez Cove Formation generally (acknowledged by Dingle et al. 1997, Dingle \& Lavelle 1998) makes the significance of the ${ }^{87} \mathrm{Sr} /{ }^{86} \mathrm{Sr}$ ages difficult to interpret, and only a general Oligocene age can currently be affirmed (see discussion later).

The age of the overlying Boy Point Formation is also not well known and has been based largely on bracketing by older and younger formations. It is generally believed to be $c$. mid-Oligocene by comparison with the age of 32-30 Ma assumed for the older Polonez Cove Formation (Birkenmajer 1989), but that is 
Table IV. Summary of ${ }^{40} \mathrm{Ar} /{ }^{39} \mathrm{Ar}$ results for King George Island lavas.

\begin{tabular}{|c|c|c|c|c|c|c|c|c|c|c|c|}
\hline Sample & Locality & Laboratory & Formation & Analysis & $n$ & ${ }^{0}{ }^{39} \mathrm{Ar}$ & MSWD & $\begin{array}{l}\text { Age } \\
\text { (Ma) }\end{array}$ & $\pm 2 \sigma$ & Adj & $\begin{array}{l}\text { Comments on age } \\
\text { spectrum }\end{array}$ \\
\hline P.2958.22 & $\begin{array}{l}\text { Crags backing Mazurek } \\
\text { Point; Oberek Cliff } \\
\text { Member }\end{array}$ & NMGL & Polonez Cove & Groundmass & 8 & 100 & 5.0 & 26.38 & 2.59 & $a$ & $\begin{array}{l}\text { Low yields, poor } \\
\text { precision }\end{array}$ \\
\hline P.2962.1 & $\begin{array}{l}\text { Magda Nunatak; } \\
\text { Oberek Cliff Member }\end{array}$ & NMGL & Polonez Cove & Groundmass & 9 & 100 & 3.3 & 25.90 & 1.30 & $a$ & $\begin{array}{l}\text { Flat spectrum, fair } \\
\text { precision }\end{array}$ \\
\hline P.2960.22 & $\begin{array}{l}\text { South of Battke Point; } \\
\text { Low Head Member }\end{array}$ & NMGL & Polonez Cove & Groundmass & 8 & 100 & 1.9 & 27.56 & 0.66 & & $\begin{array}{l}\text { Flat spectrum, poor } \\
\text { precision }\end{array}$ \\
\hline P. 2007.2 & $\begin{array}{l}\text { Low Head; Low Head } \\
\text { Member }\end{array}$ & NMGL & Polonez Cove & Groundmass & 9 & 100 & 4.7 & 26.73 & 1.19 & $a$ & Minor recoil \\
\hline P. 2767.11 & Krakowiak Crag & NMGL & Boy Point & Hornblende & 11 & 100 & 1.0 & 26.80 & 0.69 & & $\begin{array}{l}\text { Flat spectrum, low } \\
\text { precision }\end{array}$ \\
\hline P.2766.5 & Chopin Ridge & NMGL & Boy Point & Groundmass & 9 & 100 & 22.6 & 25.23 & 0.97 & $a$ & Recoil \\
\hline P. $2774.10 \mathrm{~B}$ & $\begin{array}{l}\text { Dunikowski Ridge, } \\
\text { Cinder Spur }\end{array}$ & NMGL & Cinder Spur & Groundmass & 8 & 100 & 8.8 & 24.88 & 1.20 & $a$ & Recoil, good precision \\
\hline P.2801.4 & Malczewski Point & NMGL & Cinder Spur & Groundmass & 9 & 100 & 12.5 & 25.08 & 0.73 & $a$ & $\begin{array}{l}\text { Good precision, minor } \\
\text { recoil }\end{array}$ \\
\hline P.2797.6A & Martins Head, summit & NMGL & Cinder Spur & Groundmass & 9 & 100 & 38.1 & 25.25 & 1.75 & $a$ & Recoil, good precision \\
\hline P.2797.6B & Martins Head, summit & NMGL & Cinder Spur & Groundmass & 9 & 100 & 51.3 & 24.99 & 1.38 & $a$ & $\begin{array}{l}\text { Repeat analysis; recoil, } \\
\text { irregular spectrum }\end{array}$ \\
\hline P. 2797.10 & $\begin{array}{l}\text { Martins Head, summit; } \\
\text { below P.2797.6A }\end{array}$ & NMGL & Cinder Spur & Groundmass & 9 & 100 & 51.3 & 25.34 & 1.54 & $a$ & Recoil, good precision \\
\hline P.2788.6 & Harnasie Hill (plug) & Leeds & $\begin{array}{l}\text { Cape Syrezol } \\
\text { Group }\end{array}$ & WR & 8 & 86.2 & 1.0 & 27.10 & 1.40 & & $\begin{array}{l}\text { Slightly disturbed } \\
\text { spectrum but } \\
\text { well-defined plateau }\end{array}$ \\
\hline P.2903.12 & $\begin{array}{l}\text { Crab Creek, Cape } \\
\text { Melville }\end{array}$ & NMGL & $\begin{array}{l}\text { Cape } \\
\text { Melville }\end{array}$ & Hornblende & 8 & 100.0 & 3.4 & 21.25 & 3.14 & $a$ & $\begin{array}{l}\text { Fairly flat spectrum, low } \\
\text { precision }\end{array}$ \\
\hline
\end{tabular}

Notes: NMGL = New Mexico Geochronology Laboratory; WR = whole-rock crushed sample; $n=$ number of heating steps; $\%{ }^{39} \mathrm{Ar}=$ total fraction of gas released used in calculation of weighted mean age (always 100\% for these recoil-prone samples, as discussed in Supplemental Information S2); Adj denotes high-MSWD samples with weighted mean errors multiplied by the square root of the MSWD.

${ }^{a}$ Calculated using Taylor/Mahon error (see Supplemental Information S2).

apparently contradicted by a single published relatively imprecise ${ }^{40} \mathrm{Ar} /{ }^{39} \mathrm{Ar}$ age of $22.6 \pm 1.7 \mathrm{Ma}$ for a Boy Point Formation lava (Smellie et al. 1998) and a K-Ar age of $>23.6 \pm 0.3 \mathrm{Ma}$ for the basal lava of the Boy Point Formation, believed to be younged and not a true eruptive age (Birkenmajer et al. 1986). K-Ar ages determined on the younger Cinder Spur Formation vary from $30.8 \pm 2.0 \mathrm{Ma}$ to $20.4 \pm 2.4 \mathrm{Ma}$ for lavas at Cinder Spur, $29.5 \pm 2.1 \mathrm{Ma}$ for lava at the top of Martins Head, to $17.3 \pm 1.3 \mathrm{Ma}$ for a tiny lava outcrop at Vauréal Peak (Birkenmajer et al. 1986, 1989). The youngest two ages were thought to be reset (Birkenmajer \& Gaździcki 1986); the small outcrop at Vauréal Peak is now thought to be a megaclast of the Cinder Spur Formation reworked within the Vauréal Peak Formation (Smellie et al. 2021). Lastly, intrusions in the area were grouped by Birkenmajer (1982) into the Cape Syrezol Group. The only isotopic ages for the intrusions, all but one determined by the K-Ar method, are consistently Oligocene and Miocene. They comprise K-Ar ages of
21.8 \pm 0.6 Ma for the Chopin Dyke, $21.9 \pm 1.1 \mathrm{Ma}$ for the Cinder Spur mega-dyke and $30.5 \pm 5.5$ and $25.7 \pm 0.7$ for dykes at Harnasie Hill (Birkenmajer \& Gaździcki 1986, Birkenmajer et al. 1989). ${ }^{40} \mathrm{Ar} /{ }^{39} \mathrm{Ar}$ ages obtained on the Chopin Dyke $(21.3 \pm 1.6 ; 21.4 \pm 1.9 \mathrm{Ma})$ are indistinguishable from the $\mathrm{K}-\mathrm{Ar}$ age (Smellie et al. 1998). Despite the 'plug' at Low Head initially yielding a $\mathrm{K}-\mathrm{Ar}$ age of $14.4 \pm 1.4 \mathrm{Ma}$, which influenced its interpretation (Birkenmajer et al. 1986), later dating by ${ }^{40} \mathrm{Ar} /{ }^{39} \mathrm{Ar}$ yielded older imprecise ages of $24 \pm 2 \mathrm{Ma}$ (Keller et al. 1992) and $23.7 \pm 2.0 \mathrm{Ma}$ (Smellie et al. 1998). Moreover, the surrounding breccia yielded a K-Ar age of $22.3 \pm 0.8 \mathrm{Ma}$ (Birkenmajer et al. 1991b), which is consistent with its cogeneity with the associated dome outcrop. Finally, a single preliminary ${ }^{40} \mathrm{Ar} /{ }^{39} \mathrm{Ar}$ age of $20.98 \pm 3.14 \mathrm{Ma}$ for the Cape Melville Formation was published by Troedson \& Riding (2002), but without supporting data. Although the Cape Melville Formation has been well studied and is not part of our study (for stratigraphical and lithofacies details, see Troedson \& 


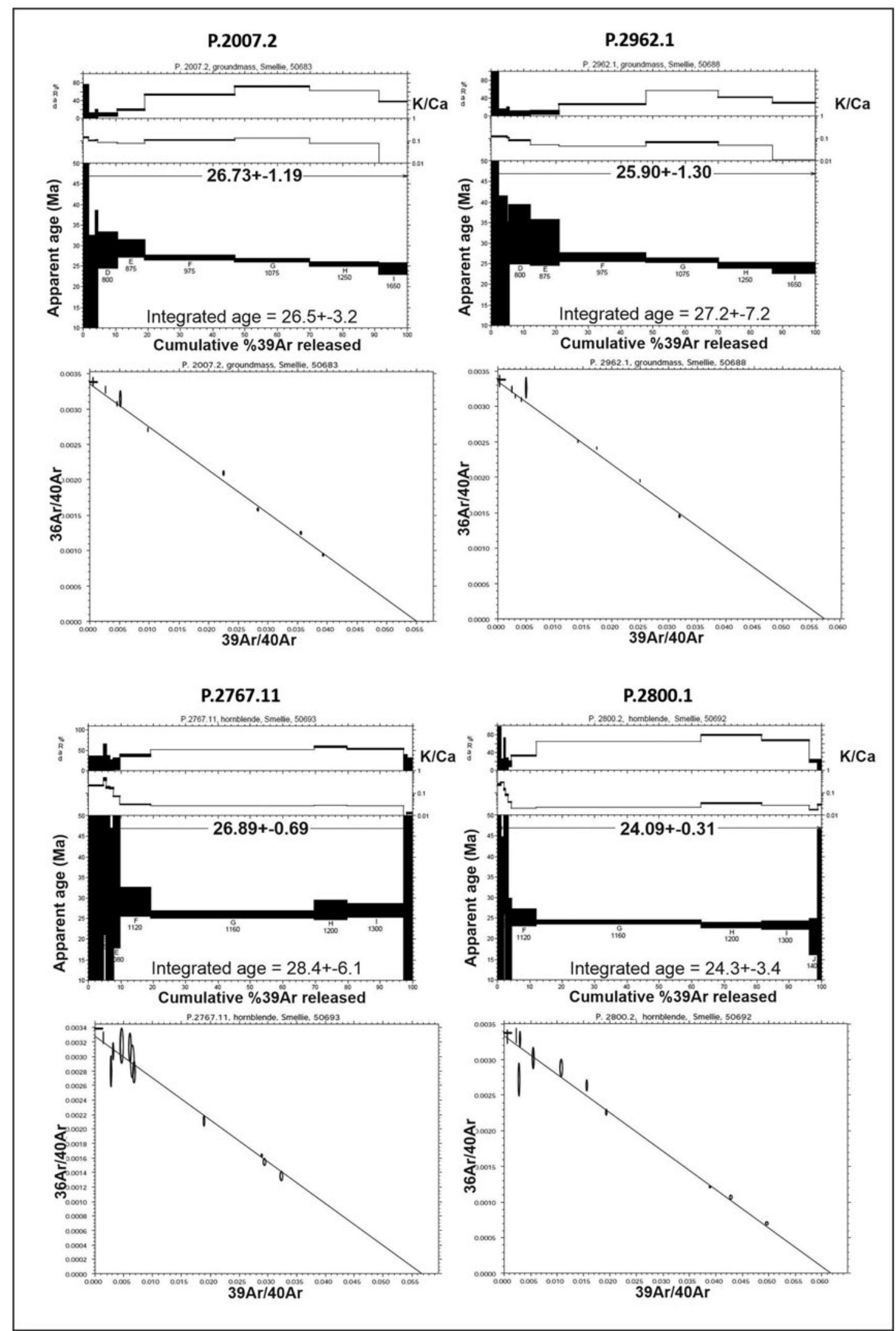

Fig. 16. Representative ${ }^{40} \mathrm{Ar} /{ }^{39} \mathrm{Ar}$ age spectra for lava samples from the Polonez Cove Formation (P.2007.2; P.2962.1), the Boy Point Formation (P.2767.11) and the Cinder Spur Formation (P.2800.1, P.2801.4), and a tuff from the Cape Melville Formation (P.2903.12). See Table 2 and Supplemental Information S2 for analytical details. 


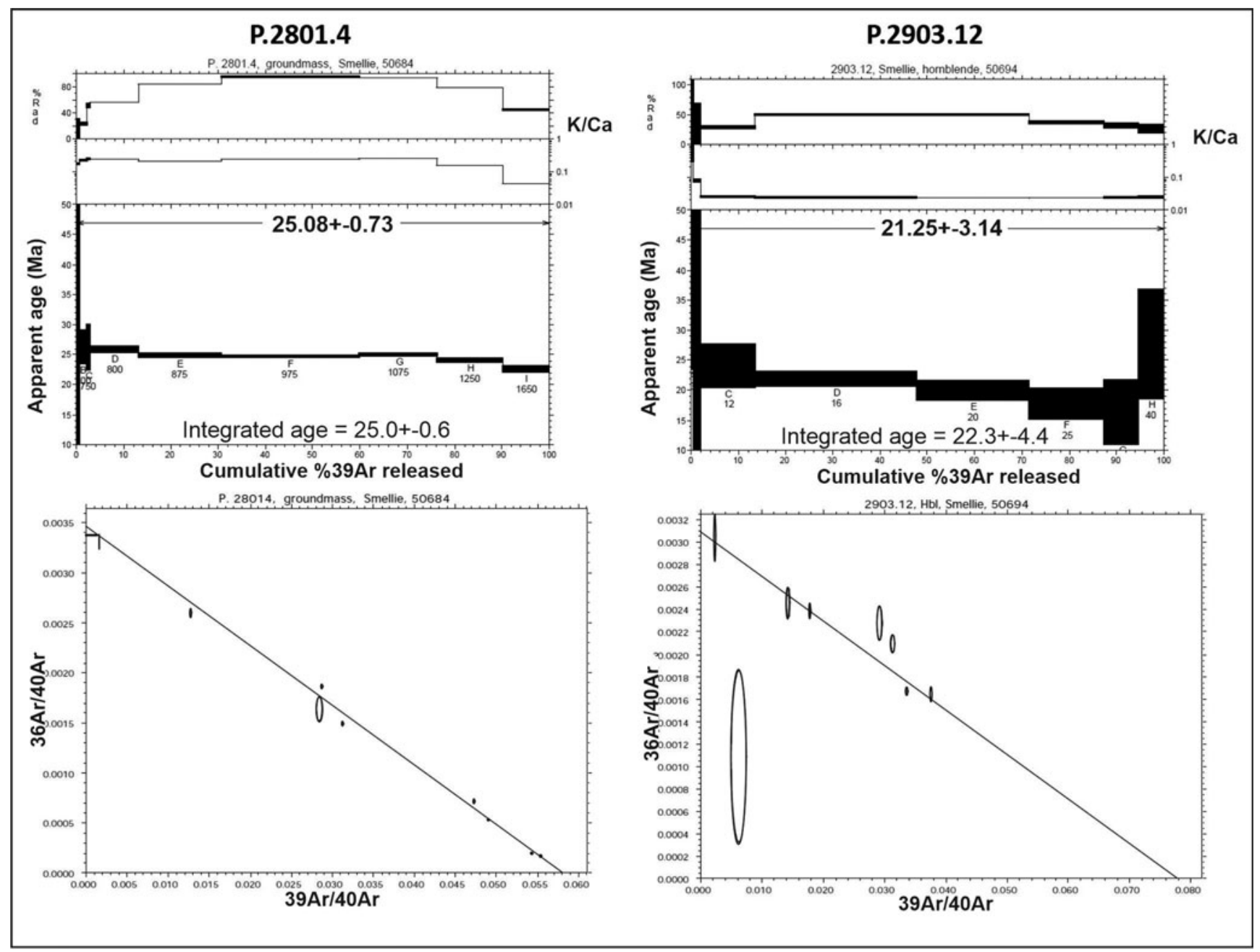

Fig. 16. Continued.

Riding 2002), refining its age is relevant to understanding the development of Oligocene-Miocene formations on King George Island, and it is included here for completeness.

\section{Results of new ${ }^{40}$ Ar ${ }^{39}$ Ar dating}

A total of 15 samples were dated, including a tuff interbedded with the glacio-marine Cape Melville Formation (Table IV, new Ar ages). Representative ${ }^{40} \mathrm{Ar} /{ }^{39} \mathrm{Ar}$ age spectra are shown in Fig. 16. Details of the methods used, analytical information, step-heating spectra and isotope correlation plots for all of the dated samples are provided in Supplemental Information S2. All errors quoted are $2 \sigma$. The sample locations and new ages, together with previously published ages, are shown in Figs 3, 9, 12, 13 \& 14.

Polonez Cove Formation: Four samples were dated from volcanic members in the Polonez Cove Formation, in its type area and at Magda Nunatak. They include lavas from the Low Head and Oberek Cliff members and the small lava dome at Low Head (also Low Head Member). The new ages reported in this paper (Table IV) are stratigraphically consistent and within error, although the errors are relatively large. The new ages vary from $25.90 \pm 1.30 \quad$ Ma (Magda Nunatak; Oberek Cliff Member; Fig. 17) to $27.56 \pm 0.66$ and $26.38 \pm 2.59 \mathrm{Ma}$ south of Battke Point (Low Head Member) and facing Mazurek Point (Oberek Cliff Member). The Low Head dome (basal Low Head Member) is dated as $26.73 \pm 1.19 \mathrm{Ma}$ (Fig. 16). Together they provide a mean age for the Polonez Cove Formation (above the Krakowiak Glacier Member) of c. $26.64 \pm 1.43 \mathrm{Ma}$. The data suggest that the duration of deposition was potentially c. $1.7 \mathrm{~m} . \mathrm{y}$. (27.6-25.9 Ma). However, the age range probably indicates that some of the Ar dates are less accurate than others for undetermined reasons (e.g. unrecognized minor Ar loss or gain). The new ages are still likely to be much more accurate than the previous data, and they cover a narrower age range. 


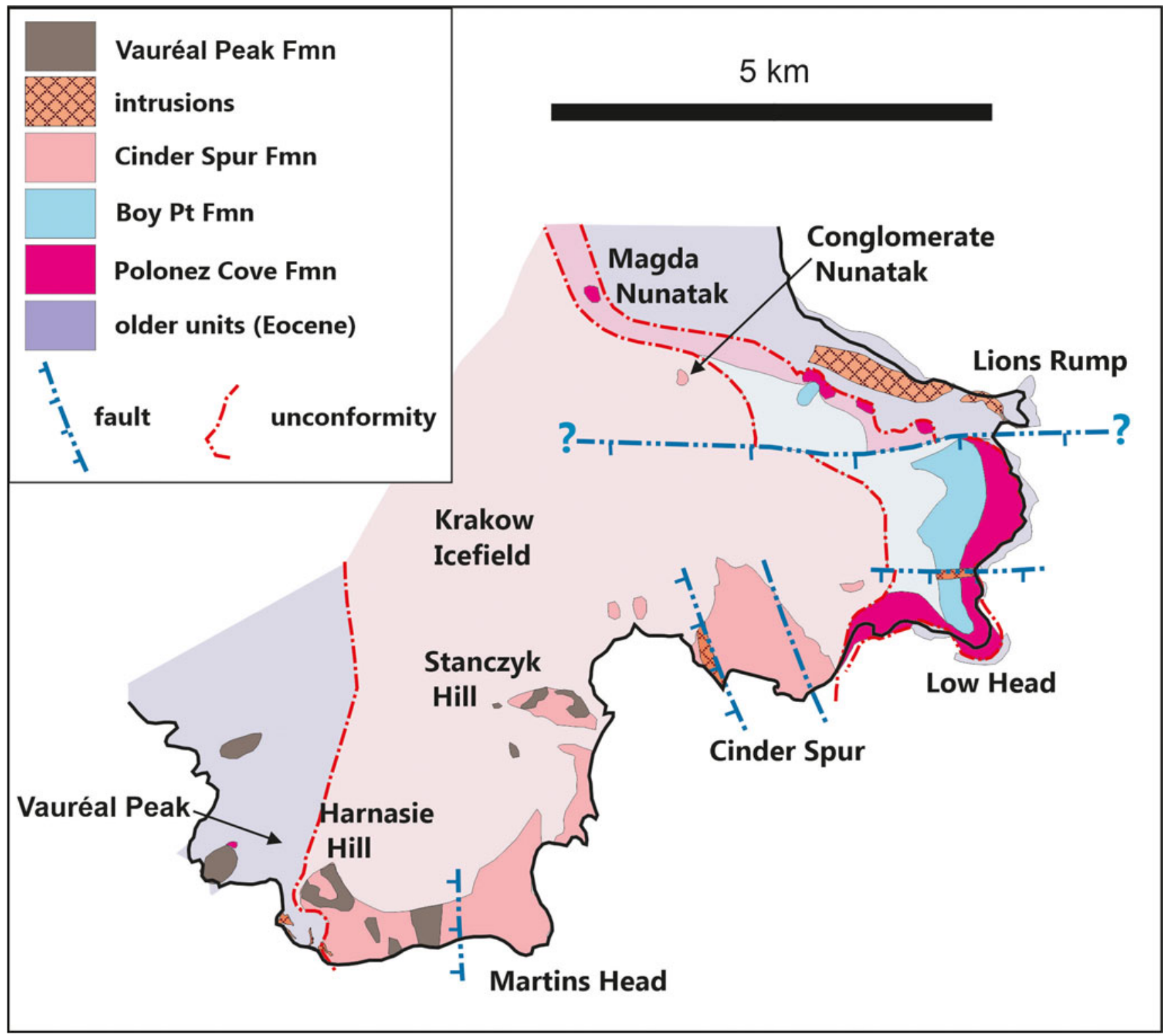

Fig. 17. Geological sketch map of volcanic and sedimentary outcrops on the south-east coast of King George Island, based on the present study.

Boy Point Formation: The two samples from the Boy Point Formation dated by us are andesite lavas. They gave ages of $26.80 \pm 0.69$ Ma (L3; Fig. 16) and $25.23 \pm 0.97 \mathrm{Ma}$ (L2). Disregarding the K-Ar age, which is significantly younger and not within error of our two new ${ }^{40} \mathrm{Ar} /{ }^{39} \mathrm{Ar}$ ages, the three ${ }^{40} \mathrm{Ar} /{ }^{39} \mathrm{Ar}$ ages are cumulatively within error. However, the two new ages reported here contradict the mapped stratigraphical succession. The younger age is from the outcrop of L2 within $50 \mathrm{~m}$ of the very large Chopin Dyke, and it may have suffered some thermal resetting. The new age for L3 overlaps with the youngest age obtained on the underlying Polonez Cove Formation, suggesting that no significant gap in time occurred prior to construction of the Boy Point Formation, and deposition may have been essentially continuous or with a geologically short break. This is consistent with the presence of marine fossils in interbedded sedimentary rocks (subunit S4) and the evidence for pervasive brecciation of the lavas, signifying immersion in water and a possible marine eruptive setting for both formations. The two new samples are probably the most accurate. They have a mean age of c. $26.02 \pm 0.83 \mathrm{Ma}$, which is our best estimate for the age of the lava-dominated upper Boy Point Formation.

Cinder Spur Formation: Six lavas were dated from major outcrops of the Cinder Spur Formation (Figs 9, 13 \& 14). Although not within error, the new ages are well clustered, with a limited range varying from $25.42 \pm 0.88$ to 
$24.09 \pm 0.31 \mathrm{Ma}$ (Fig. 16). The published K-Ar ages have a much wider range $(30.8 \pm 2.0$ to $20.4 \pm 2.4 \mathrm{Ma})$ that wholly encompasses the new ${ }^{40} \mathrm{Ar} /{ }^{39} \mathrm{Ar}$ ages, suggesting that the new ages are more precise. Although the mean age of the new data is $25.01 \pm 1.11 \mathrm{Ma}$, prominent erosional unconformities are present within the formation in the type area at Cinder Spur and are of uncertain duration (Figs 9 \& 10). The stratigraphical limits of the formation are also ill-defined, implying that the full range of ages may not have been tested. The base is unexposed (presumably younger than the Boy Point Formation, with a mean age of $26.02 \pm 0.83 \mathrm{Ma}$ ). The youngest age determined for a lava in the Boy Point Formation $(25.23 \pm 0.97 \mathrm{Ma})$ overlaps with older ages for lavas in the Cinder Spur Formation. Thus, the possibility exists that the two formations might overlap in time, perhaps by interfingering. However, field relationships mapped at the eastern margin of the Cinder Spur outcrop, where the Boy Point Formation is removed entirely together with most of the Polonez Cove Formation (Fig. 9), suggest that a prominent erosional unconformity is present, consistent with different ages. The Cinder Spur Formation is overlain by the Vauréal Peak Formation, across a profound erosional unconformity, and there is evidence for a large time gap (see below).

Intrusions: Only one intrusion was dated during this study: the plug-like outcrop that intrudes Cinder Spur Formation strata at Harnasie Hill (Fig. 12). The sample is very fresh, with much unaltered olivine, and it yielded a slightly disturbed but well-defined plateau age of $27.1 \pm 1.4 \mathrm{Ma}$. The new age is the second oldest age in our dataset, older even than the ages for the Polonez Cove Formation, which is known to be older than the Cinder Spur Formation.

Cape Melville Formation: In our study, a hornblende separate from a tuff interbedded with the Cape Melville Formation at Cape Melville yielded an age of $21.25 \pm 3.14 \mathrm{Ma}$ (Fig. 16). Despite the large error, the age is stratigraphically consistent with the other available ages for associated rocks on the headland.

\section{Discussion}

Age of Oligocene-Miocene sedimentation and volcanism on eastern King George Island

Our study has significantly revised the stratigraphy of sedimentary and volcanic formations on eastern King George Island and established their ages more reliably (Table II). Most of the geological units have Late Oligocene ages (Chattian), with a probable narrow spread of $c . \leq 2 \mathrm{~m} . \mathrm{y}$. Based on the new mapping and chronology, a revised map showing the likely distribution of the Oligocene formations on eastern King George Island is shown in Fig. 17.
The age of the Polonez Cove Formation was previously based on imprecise palaeontological and potentially unreliable $\mathrm{Sr}$ isotopic ages. Our ${ }^{40} \mathrm{Ar} /{ }^{39} \mathrm{Ar}$ ages on interbedded lavas indicate that the formation was deposited at c. 26.64 $\pm 1.43 \mathrm{Ma}$ (a mean of four ${ }^{40} \mathrm{Ar} /{ }^{39} \mathrm{Ar}$ ages). The duration of deposition would have been relatively short if the sequence represents a single glacial-deglacial cycle (Porebski \& Gradziński 1987, Troedson \& Smellie 2002). The new ages strictly only apply to the basalt volcanism-sourced members, and the Polonez Glaciation itself, represented by the basal Krakowiak Glacier Member diamictites, is not dated directly. However, it is likely that its age is only slightly older than that of the succeeding members.

The new ages are consistently slightly older, by up to 4 m.y., than other ${ }^{40} \mathrm{Ar} /{ }^{39} \mathrm{Ar}$ ages previously published (most without supporting data) for the same geological units (Fig. 3; Keller et al. 1992, Smellie et al. 1998, Troedson \& Smellie 2002), for reasons unknown. Our ${ }^{40} \mathrm{Ar} /{ }^{39} \mathrm{Ar}$ ages are also c. $2-3 \mathrm{~m} . \mathrm{y}$. younger than the published ${ }^{87} \mathrm{Sr} /{ }^{86} \mathrm{Sr}$ ages. A similar consistent age disparity between $\mathrm{Sr}$ ages from fossil bivalves and $\mathrm{Ar}$ ages from lavas occurs in the mainly Pliocene James Ross Island Volcanic Group, on the east flank of northern Antarctic Peninsula (Fig. 1). The disparity was explained as being a consequence of mixing between inshore seawater and freshwater runoff affected by equilibration, with lavas containing low ${ }^{87} \mathrm{Sr} /{ }^{86} \mathrm{Sr}$ ratios. Because of the low gradient of the $\mathrm{Sr}$ seawater curve during the Pliocene, the slightly lower ${ }^{87} \mathrm{Sr} /{ }^{86} \mathrm{Sr}$ ratios would create artificially older ages (Smellie 2021b). However, the reference $\mathrm{Sr}$ dating curve for the Oligocene is not as flat as in the Pliocene (McArthur et al. 2001), so slight changes in the $\mathrm{Sr}$ ratios should not have such a noticeable effect on the ages. We suggest that pervasive alteration observed in most of the Sr-dated shelly fossils in the Polonez Cove Formation (Dingle et al. 1997, acknowledged by the authors) is probably the major effect responsible for the older ages. The $\mathrm{Sr}$ results should thus be regarded as suspect and Ar ages used in preference. Our best estimate for the depositional age of the Polonez Cove Formation is therefore $c$. $26.64 \pm 1.43 \mathrm{Ma}$. On the basis of high $\delta^{18} \mathrm{O}$ values of benthic foraminifera in a high-resolution study, Hauptvogel et al. (2017) suggested that Antarctica was heavily glaciated between 27.8 and $24.5 \mathrm{Ma}$ (a period that includes the Oi2b event $(26.7 \mathrm{Ma}))$, consistent with an ice sheet similar to or larger than present and with no sign of a significant collapse during interglacials. With the Polonez Glaciation now also dated as c. 26.7 Ma, we suggest that it can be correlated with Oi2b with considerable confidence.

Published ages for the Boy Point Formation, as now defined, are $>23.6 \pm 0.3 \mathrm{Ma}$ for L1 (by K-Ar; Birkenmajer et al. 1986) and 22.6 $\pm 1.7 \mathrm{Ma}$ for L3 (by ${ }^{40} \mathrm{Ar} /{ }^{39} \mathrm{Ar}$; Smellie et al. 1998). The new dated samples 
confirm the Oligocene age inferred previously, although they are considerably younger than the c. 33-30 Ma age previously assumed (Birkenmajer 1989). We suggest that the formation has an age of $c .26 .02 \pm 0.83 \mathrm{Ma}$. This is the mean of our two dated samples; it dates the upper, lava-dominated part of the formation. The formation was previously assumed to directly overlie the Polonez Cove Formation and then was itself overlain by the Wesele Cove Formation (Birkenmajer 1982). However, the latter (now regarded as a member) is interbedded with lavas of the Boy Point Formation, although it also locally forms the basal unit of the formation and progrades northwards across the Polonez Cove Formation for much of its extent, a reverse of the originally published relationships. The remarkable similarity between the ages of the Polonez Cove and Boy Point formations indicates that they were formed within a short period of time, and the lithofacies suggest that they were both formed in a marine environmental setting. The several unconformities mapped in the two constituent formations therefore have little time significance.

The Cinder Spur Formation is formed of subaerial basalt lavas and interbedded fluvial and mass-flow deposits. It is newly defined in this paper and is an amalgamation of three previously described formations (Martins Head, Harnasie Hill and Dunikowski Ridge formations). It is the most geographically extensive formation investigated in the study and indicates a significant episode of volcanism. Previously published ages had a very wide spread ( $30.8 \pm 2.0$ to $20.4 \pm 2.4 \mathrm{Ma}$, possibly ranging up to $17.3 \pm 1.3 \mathrm{Ma}$ ). Several of the ages were regarded as having been younged because they conflicted with the observed or inferred order of succession, possibly due to local reheating and Ar loss (Birkenmajer et al. 1989). The formation is now reliably dated as $25.42 \pm 0.88$ to $24.09 \pm 0.31$ Ma (mean age: $25.01 \pm 1.11 \mathrm{Ma}$ ). Although its base is unexposed, the new ages indicate that the eruptive episode probably followed shortly after that of the Boy Point Formation and the two formations are petrologically similar. Although some overlap in age is possible, the field relationships suggest that deep erosion of the Boy Point Formation occurred before eruption of the Cinder Spur Formation as a result of a significant episode of uplift of at least $200 \mathrm{~m}$. Like formations in the marine Chopin Ridge Group, the several unconformities mapped at the base of and within the Cinder Spur Formation probably represent relatively little geological time. It is also notable that the ages obtained for the Cinder Spur Formation overlap with those determined for the marine Destruction Bay Formation at Cape Melville $(23.6 \pm 0.7 \mathrm{Ma}$ (by K-Ar; Birkenmajer et al. 1988b) or $25.3 \pm 0.8 \mathrm{Ma}$ (by ${ }^{87} \mathrm{Sr} /{ }^{86} \mathrm{Sr}$, mean age; Dingle \& Lavelle 1998; Fig. 1)) and it seems likely that the latter is a distal equivalent of the Cinder Spur Formation. A correlation between the two is further supported by the presence of detrital amphibole in the Destruction Bay sediments (Troedson \& Riding 2002), an otherwise rare volcanic mineral in the South Shetland Islands that is common and conspicuous in the Cinder Spur Formation (Smellie et al. 1984).

The Cinder Spur Formation is overlain by the Vauréal Peak Formation, a massive diamictite of glacial origin (i.e. a tillite; Birkenmajer 1982). The age of the Vauréal Peak Formation is unknown but was previously inferred to be comparable with that of the underlying lavas (i.e. c. 30-26 Ma). It lacks contemporaneous dateable lavas and is not cross-cut by intrusions; dating of lava clasts has yielded only provenance ages (e.g. Birkenmajer et al. 1989, Smellie et al. 2021). The diamict and volcanic formations were combined within the Legru Bay Group to define the local Legru Glacial (Birkenmajer et al. 1982; group name now defunct). However, although previous authors acknowledged that the base of the Vauréal Peak Formation is incised into the underlying volcanic strata, the significance of that erosion has never been addressed. For example, it cuts down at least $250 \mathrm{~m}$ at the Cliffs of Gloom and Stanczyk Hill (Fig. 15; see also Fig. 7h). Moreover, from the orientation of strata in the different outcrops of the Cinder Spur Formation, the original edifices responsible for the volcanism must have extended into Bransfield Strait and have been significantly cut back by marine erosion (Fig. 11). The mapped outcrops of the Vauréal Peak Formation (Figs 12 \& 13) indicate exhumation of a palaeotopography that included a south-facing cliff and a deep coastal embayment, corresponding to the Cliffs of Gloom and Legru Bay, respectively. The palaeotopography indicates a coastline very much like that of today. The implication is that the southern margin of King George Island had already undergone severe marine erosion prior to deposition of the Vauréal Peak Formation. Therefore, a much younger age than previously assumed is indicated. Although the age is unknown, it is estimated conservatively to be $\leq 10 \mathrm{Ma}$.

A precise palaeontological age for the glacio-marine Cape Melville Formation, on easternmost King George Island, has proven elusive despite an abundance of in situ macrofossils, but benthic foraminifera suggest that the formation is Early Miocene (Birkenmajer \& Luczkowska 1987). Bracketing by field relationships indicates a maximum age of $<25.3 \pm 0.8$ or $<23.6 \pm 0.7 \mathrm{Ma}$ (by ${ }^{87} \mathrm{Sr} /{ }^{86} \mathrm{Sr}$ and $\mathrm{K}-\mathrm{Ar}$ dating, respectively) obtained on brachiopods and a basaltic tuff, respectively, in the underlying marine sedimentary Destruction Bay Formation (Birkenmajer et al. 1985, 1988b, Dingle \& Lavelle 1998). Similarly, dykes cross-cutting the Cape Melville Formation yielded K-Ar minimum ages of $20.1 \pm 0.2$ and $>19.9 \pm 0.3 \mathrm{Ma}$ (Birkenmajer et al. 1985). No interaction between the dykes and sediments has been described that might suggest they were 
contemporary. Our dating of a tuff interbedded with the Cape Melville Formation as $21.25 \pm 3.14 \mathrm{Ma}$ (Early Miocene (Aquitanian)) has helped to define more precisely its depositional age. The age is slightly younger than, but within error of, an inferred $\mathrm{Sr}$ age of $22.6 \pm 0.4 \mathrm{Ma}$ obtained on skeletal carbonate from the upper part of the Cape Melville Formation by Dingle \& Lavelle (1998). Consideration of all the available data suggests that the depositional age of the Cape Melville Formation is now relatively well defined at $c$. 22-21 Ma. It thus corresponds to the Mila glacial (c. 21.8 Ma, or possibly $21.24 \mathrm{Ma}$; Cooke et al. 2008).

Finally, only one hypabyssal intrusion was dated during our study: a plug at Harnasie Hill. Adjacent dykes have broadly similar K-Ar ages (30.5 \pm 5.5 and $25.7 \pm 0.7 \mathrm{Ma}$; Birkenmajer et al. 1989), and hypabyssal intrusions on western King George Island have yielded comparable ages of $27.9 \pm 0.3$ and $25.4 \pm 0.4 \mathrm{Ma}$ (by U-Pb, on zircon; Pańczyk et al. 2009). However, the youngest age for the Cinder Spur Formation is $24.09 \pm 0.31 \mathrm{Ma}$ (Table IV), which can be regarded as a maximum age for the intrusions at Harnasie Hill. Thus, the field relations suggest that excess Ar may have affected all three dated samples at that locality. Further dating, preferably by the U-Pb method (e.g. Pańczyk et al. 2009, Nawrocki et al. 2010, 2011), is required to establish the ages of these intrusions.

If our interpretation of the field relations at Cape Melville is correct, the so-called Sherratt Bay Formation is a sill with a likely age similar to dykes at the locality (i.e. c. $20 \mathrm{Ma}$; by $\mathrm{K}-\mathrm{Ar}$ ). Thus, it is doubtful that a single dolerite sill with no particularly distinctive characteristics should remain as a named stratigraphical unit of formation status (see also Troedson \& Riding 2002), and it is omitted from Table II on that basis. An informal name that might be used for the feature, which retains its geographical association, is the Sherratt Bay sill. Other hypabyssal intrusions on south-eastern King George Island have significantly younger ages of $21.9 \pm 1.1, \quad 21.4 \pm 1.9, \quad 21.8 \pm 0.6$, $20.1 \pm 0.2$ and $>19.9 \pm 0.3 \mathrm{Ma}$ (mean age of $21.3 \mathrm{Ma}$; by $\mathrm{K}-\mathrm{Ar}$ and ${ }^{40} \mathrm{Ar} /{ }^{39} \mathrm{Ar}$ ). The prominent clustering around 22-21 Ma implies that it was an important period of extension, faulting and intrusion. The dykes both exploited and cut across several faults (best seen at Cinder Spur; Fig. 9). The significance of the tectono-magmatic episode is uncertain, but Birkenmajer (1992) speculated that it may be linked to the early stages of opening of Bransfield Strait at 26-22 Ma.

\section{Conclusions}

King George Island, South Shetland Islands (northern Antarctic Peninsula), is host to an internationally renowned series of volcanic and sedimentary sequences that preserve evidence for multiple glacial episodes, of which four have previously been described. No comparable strata are exposed anywhere else on Antarctica. New mapping and ${ }^{40} \mathrm{Ar} /{ }^{39} \mathrm{Ar}$ chronological studies of the sequences show that the established stratigraphy and chronology require significant revision. In particular, the existence of an Eocene glaciation (Kraków Glaciation) is conclusively disproved, and the presence of Eocene alpine glaciers (represented by the 'Hervé Cove tillite') on King George Island is also shown to be unproven. The 'Mazurek Point Formation' (now called the Hennequin Formation) is Eocene in age and wholly unrelated in its lithofacies and eruptive setting (subaerial) to much younger members of the Chopin Ridge Group, which formed in a marine setting. It is thus no longer regarded as a valid part of that group, and the revised stratigraphical succession (Chopin Ridge group) now comprises only the Polonez Cove and Boy Point formations, both of which were deposited within a narrow time interval at c. 26.7-26.0 Ma. The lithostratigraphical basis for four other formations (Dunikowski Ridge, Harnasie Hill, Martins Head and Vauréal Peak formations), which together formerly comprised the Legru Bay Group, is also suspect. The basal three formations are combined into a single new unit (Cinder Spur Formation; 25.01 $\pm 1.11 \mathrm{Ma}$ ) composed of subaerial basalt lavas and fluvial and mass-flow sedimentary deposits, and no group name is required. Most of the formations described in this paper are Late Oligocene (Chattian) in age, and they are all shown to have been deposited in a narrow time interval, probably $\leq 2 \mathrm{~m}$.y., despite the presence of numerous unconformities between and within several of the units. Dating of a tuff interbedded with the Cape Melville Formation has confirmed its age as Early Miocene (c. 22-21 Ma; Aquitanian). Finally, the Vauréal Peak Formation, composed of diamict interpreted as a tillite, is shown to drape a palaeolandscape very similar to today, including deep coastal embayments and sea-facing cliffs, which implies that it is much younger than previously envisaged. As a consequence of the revised stratigraphy and new ${ }^{40} \mathrm{Ar} /{ }^{39} \mathrm{Ar}$ chronological results, the ages of the three major glacial episodes represented on King George Island are determined to be c. 26.7 Ma (Polonez Glaciation), probably c. $21.8 \mathrm{Ma}$ (Melville Glaciation) and $c . \leq 10 \mathrm{Ma}$ (Legru Glaciation). The two main glacial episodes can thus be correlated with the Oi2b and Mila global isotope stages, respectively.

\section{Acknowledgements}

The authors are very grateful to the British Antarctic Survey and the University of Leeds for their support of this investigation. We are also grateful for the help of 
Andy Teasdale, Carl Haberl, Filipo Croso and Anne Flink during fieldwork by the authors on King George Island. Phil Guise is thanked for his help and guidance with the geochronology at Leeds University. The authors also gratefully thank the captains, officers and crews of HMS Endurance, HMS Protector, RRS Bransfield and RRS Shackleton for their invaluable logistical support, and Mike Tabecki (BAS) and Annika Burns (Leicester) for making the numerous thin sections from challenging samples that are at the heart of this study. JLS also gratefully thanks Professors Tony Rocha-Campos and Paulo dos Santos and the logistical support of the Brazilian Antarctic Programme (PROANTAR; i.e. Programa Antártico Brasiliero) for his invited visit to King George Island in 2014. JLS is also very grateful to Ray Burgess (Manchester University, UK) for discussions on ${ }^{40} \mathrm{Ar} /{ }^{39} \mathrm{Ar}$ data. We are also grateful to Teal Riley and Jerzy Nawrocki for their careful reviews of this paper; Ieuan Hopkins and Kevin Roberts (British Antarctic Survey Archive Service) for helping with access to archived field data; and Beverley Ager and Mandy Tomsett (British Antarctic Survey Library) for obtaining copies of hard-to-access papers relating to this study.

\section{Author contributions}

JLS: conceptualization (lead), data acquisition (equal), data curation (equal), formal analysis (lead), funding acquisition (lead), investigation (lead), writing - original draft (lead), writing - review and editing (lead).

WCM: conceptualization (supporting), data acquisition (equal), data curation (equal), formal analysis (equal), investigation (supporting), writing - original draft (supporting), writing - review and editing (supporting).

RW: conceptualization (supporting), data acquisition (equal), data curation (equal), formal analysis (supporting), investigation (supporting), writing original draft (supporting), writing - review and editing (equal).

AT: conceptualization (supporting), data acquisition (equal), data curation (equal), formal analysis (equal), investigation (supporting), writing - original draft (supporting), writing - review and editing (equal).

RJH: conceptualization (supporting), data acquisition (supporting), data curation (supporting), formal analysis (supporting), investigation (equal), writing - original draft (supporting), writing - review and editing (equal).

\section{Supplemental material}

Four supplemental information files will be found at https://doi.org/10.1017/S095410202100033X.

\section{References}

Barton, CM. 1965. The geology of the South Shetland Islands. Part 3: the stratigraphy of King George Island. British Antarctic Survey Scientific Reports, 44, 1-33.

Birkenmajer, K. 1980. Discovery of Pliocene glaciation on King George Island, South Shetland Islands (West Antarctica). Bulletin of the Polish Academy of Sciences, Earth Sciences, 27, 59-67.

Birkenmajer, K. 1982. Pliocene tillite-bearing succession of King George Island (South Shetland Islands, Antarctica). Studia Geologica Polonica, 74, 7-72.

BirkenMAJER, K. 1987. Oligocene-Miocene glacio-marine sequences of King George Island (South Shetland Islands), Antarctica. Palaeontologia Polonica, 49, 9-36.

Birkenmajer, K. 1989. A guide to Tertiary geochronology of King George Island, West Antarctica. Polish Polar Research, 10, 555-579.

Birkenmajer, K. 1990. Geochronology and climatology of Tertiary glacial and interglacial successions on King George Island, South Shetland Islands (West Antarctica). Zentralblatt für Geologie und Paläontologie, Teil I, Geologie, 141-151.

Birkenmajer, K. 1992. Evolution of the Bransfield Basin and rift, West Antarctica. In Yoshida, Y., Kaminuma, K. \& Shiraishi, K., eds. Recent progress in Antarctic earth science. Tokyo: Terra Scientific Publishing Company (Terrapub), 405-410.

Birkenmajer, K. 1994. Geology of Tertiary glacigenic deposits and volcanics (Polonia Glacier Group and Chopin Ridge Group) at Lions Rump (SSSI No 34), King George Island, West Antarctica. Bulletin of the Polish Academy of Sciences, Earth Sciences, 42, 165-180.

BirKenMAJER, K. 1995a. Basal and intraformational unconformities in Lower Oligocene glacigenic deposits (Polonez Cove Formation), King George Island, South Shetland Islands (West Antarctica). Studia Geologica Polonica, 107, 93-123.

Birkenmajer, K. 1995b. The Cape Melville Formation (Lower Miocene glacio-marine deposits) on King George Island, South Shetland Islands (West Antarctica): its basal and top strata. Bulletin of the Polish Academy of Sciences, Earth Sciences, 43, 113-122.

Birkenmajer, K. 2001. Mesozoic and Cenozoic stratigraphic units in parts of the South Shetland Islands and northern Antarctic Peninsula (as used by the Polish Antarctic Programmes). Studia Geologica Polonica, 118, 1-188.

Birkenmajer, K. \& Butkiewicz, T. 1988. Petrography and provenance of magmatic and metamorphic erratic blocks from Lower Miocene glacio-marine deposits of King George Island (South Shetland Islands, Antarctica). Studia Geologica Polonica, 95, 23-51.

Birkenmajer, K. \& Gaździcki, A. 1986. Oligocene age of the Pecten Conglomerate on King George Island, West Antarctica. Bulletin of the Polish Academy of Sciences, Earth Sciences, 34, 219-226.

Birkenmajer, K. \& LuczKowska, E. 1987. Foraminiferal evidence for a Lower Miocene age of glaciomarine and related strata, Moby Dick Group, King George Island (South Shetland Islands, Antarctica). Studia Geologica Polonica, 90, 81-123.

Birkenmajer, K. \& Weiser, T. 1985. Petrology and provenance of magmatic and metamorphic erratic blocks from Pliocene tillites of King George Island (South Shetland Islands, Antarctica). Studia Geologica Polonica, 81, 53-94.

Birkenmajer, K. \& Zastanniak, E. 1989. Late Cretaceous-Early Neogene vegetation history of the Antarctic Peninsula sector, Gondwana break-up and Tertiary glaciation. Bulletin of the Polish Academy of Sciences, Earth Sciences, 37, 63-88.

Birkenmajer, K., Dudziak, J. \& Tokarski, A.K. 1988a. Palaeogene calcareous nannoplankton from a neptunian dyke in the Low Head Member: its bearing on the age of the Polonez glaciation in West Antarctica. Studia Geologica Polonica, 95, 7-25.

Birkenmajer, K., Gaździcki, A. \& Krajewski, K.P. 2005. First Cenozoic glaciers in West Antarctica. Polish Polar Research, 26, 3-12. 
Birkenmajer, K., Francalanci, L. \& Peccerillo, 1991a. Petrological and geochemical constraints on the genesis of Mesozoic-Cenozoic magmatism of King George Island, South Shetland Islands, Antarctica. Antarctic Science, 3, 293-308.

Birkenmajer, K., Soliani, E. \& Kawashita, K. 1988b. Early Miocene $\mathrm{K}-\mathrm{Ar}$ age of volcanic basement of the Melville Glaciation deposits, King George Island, West Antarctica. Bulletin of the Polish Academy of Sciences, Earth Sciences, 36, 25-34.

Birkenmajer, K., Soliani, E. \& Kawashita, K. 1989. Geochronology of Tertiary glaciations on King George Island, West Antarctica. Bulletin of the Polish Academy of Sciences, Earth Sciences, 37, 27-48.

Birkenmajer, K., Gaździcki, A., Kreuzer, H. \& Müller, P. 1985. $\mathrm{K}-\mathrm{Ar}$ dating of the Melville Glaciation (Early Miocene) in West Antarctica. Bulletin of the Polish Academy of Sciences, Earth Sciences, 33, 15-23.

Birkenmajer, K., Delitala, M.C., Narębski, W., Nicoletti, M. \& Petrucciani, C. 1986. Geochronology of Tertiary island-arc volcanics and glacigenic deposits, King George Island, South Shetland Islands (West Antarctica). Bulletin of the Polish Academy of Sciences, Earth Sciences, 34, 257-273.

Birkenmajer, K., Gaździcki, A., Gradziński, R., Kreuzer, H., PoręBSKI, S.J. \& TOKARSKI, A.K. 1991b. Origin and age of pectinid-bearing conglomerate (Tertiary) on King George Island, West Antarctica. In Thomson, M.R.A., Crame, J.A. \& Thomson, J.W., eds. Geological evolution of Antarctica. Cambridge: Cambridge University Press, 663-665.

Cantrill, D. \& Poole, I. 2012. The vegetation of Antarctica through geological time. Cambridge: Cambridge University Press, 480 pp.

CAO, L. 1992. Late Cretaceous and Eocene palynofloras from Fildes Peninsula, King George Island (South Shetland Islands), Antarctica. In Yoshida, Y., Kaminuma, K. \& Shiraishi, K., eds. Recent progress in Antarctic earth science. Tokyo: Terra Scientific Publishing Company (Terrapub), 363-369.

Cooke, P.J., Nelson, C.S. \& Crundwell, M.P. 2008. Miocene isotope zones, paleotemperatures, and carbon maxima events at intermediate water-depth, Site 593, Southwest Pacific. New Zealand Journal of Geology and Geophysics, 51, 1-22.

Dingle, R.V. \& Lavelle, M. 1998. Antarctic Peninsular cryosphere: Early Oligocene (c. $30 \mathrm{Ma}$ ) initiation and a revised glacial chronology. Journal of the Geological Society, London, 155, 433-437.

Dingle, R., McArthur, J.M. \& Vroon, P. 1997. Oligocene and Pliocene interglacial events in the Antarctic Peninsula dated using strontium isotope stratigraphy. Journal of the Geological Society, London, 154, 257-264.

dos Santos, P., Rocha-Campos, A.C., Trompette, R., Uhlein, A., GIPP, M. \& SimõES, J.C. 1990. Review of Tertiary glaciation in King George Island, West Antarctica: preliminary results. Pesquisa Antartica Brasiliero, 2, 87-99.

DuPRE, D.D. 1982. Geochemistry and 40Ar/39Ar geochronology of some igneous rocks from the South Shetland Islands, Antarctica. MS thesis, Ohio State University, Columbus, 229 pp.

Dutra, T.L. \& Batten, D.J. 2000. Upper Cretaceous floras of King George Island, West Antarctica, and their palaeoenvironmental and phytogeographic implications. Cretaceous Research, 21, 181-209.

FonTES, D. \& DutRA, T.L. 2010. Paleogene imbricate-leaved podocarps from King George Island (Antarctica): assessing the geological context and botanical affinities. Revista Brasiliera de Paleontologia, 13, 189-204.

Francis, J.E., Ashworth, A., Cantrill, D.J., Crame, J.A., Howe, J., StePHENS, R., et al. 2008. 100 million years of Antarctic climate evolution: evidence from fossil plants. In COOPER, A.K., BARrett, P.J., StagG, H., Storey, B.C., Stump, E. Wise, W. \& the 10th ISAeS Editorial Team, eds. Antarctica: a keystone in a changing world. Proceedings of the 10th International Symposium on Antarctic Earth Sciences. Washington, DC: The National Academies Press, 19-27.
Fretzdorff, S., Worthington, T.J., HaAse, K.M., Hekinian, R., Franz, L., Keller, R.A. \& Stoffers, P. 2004. Magmatism in the Bransfield Basin: rifting of the South Shetland Arc? Journal of Geophysical Research, 109, 10.1029/2004JB003046.

GAŹDZICKA, E. \& GAŹDZICKI, A. 1985. Oligocene coccoliths of the Pecten Conglomerate, West Antarctica. Neues Jahrbuch für Geologie und Paläontologie, 12, 727-735.

Gaździcki, A. \& Pugaczewska, H. 1984. Biota of the 'Pecten conglomerate' (Polonez Cove Formation, Pliocene) of King George Island (South Shetland Islands, Antarctica). Studia Geologica Polonica, 79, 59-120.

Hate, K.M., Beier, C., Fretzdorff, S., Smellie, J.L. \& GARBe-SchönberG, D. 2012. Magmatic evolution of the South Shetland volcanic arc, Antarctica, and implications for continental crust formation. Contributions to Mineralogy and Petrology, 163, 1103-1119.

Hannah, M.J., Florindo, F., Harwood, D.M., Fielding, C.R. \& Cape Roberts Science Team, 2001. Chronostratigraphy of the CRP-3 drillhole, Victoria Land Basin, Antarctica. Terra Antartica, 8, 615-620.

Hauptvogel, D.W., Pekar, S.F. \& Pincay, V. 2017. Evidence for a heavily glaciated Antarctica during the late Oligocene 'warming' (27.8-24.5 Ma): stable isotope records from ODP Site 690. Paleoceanography, 32, 384-396.

Hunt, R.J. \& Poole, I. 2003. Palaeogene West Antarctic climate and vegetation history in light of new data from King George Island. Geological Society of America Special Paper, 369, 395-412.

Keller, R.A., Fisk, M.R., White, W.M. \& Birkenmajer, K. 1992. Isotopic and trace element constraints on mixing and melting models of marginal basin volcanism, Bransfield Strait, Antarctica. Earth and Planetary Science Letters, 111, 287-303.

Leat, P.T. \& Riley, T.R. 2021a. Antarctic Peninsula \& South Shetland Islands I. Volcanology. In Smellie, J.L., Panter, K.S. \& Geyer, A., eds. Volcanism in Antarctica: 200 million years of subduction, rifting and continental break-up. London: Geological Society of London, Memoir (in press).

Leat, P.T. \& Riley, T.R. 2021b. Antarctic Peninsula \& South Shetland Islands II. Petrology. In Smellie, J.L., Panter, K.S. \& Geyer, A., eds. Volcanism in Antarctica: 200 million years of subduction, rifting and continental break-up. London: Geological Society of London, Memoir (in press).

Machado, A., Chemale, F. JR, Conceição, R.V., Kawaskita, K., Morata, D., Oteíza, O. \& van Schmus, W.R. 2005. Modeling of subduction components in the genesis of the Meso-Cenozoic igneous rocks from the South Shetland arc, Antarctica. Lithos, 82, 435-543.

McArthur, J.M., Howarth, R.J. \& Bailey, T.R. 2001. Strontium isotope stratigraphy: LOWESS version 3: best fit to the marine isotope curve for 0-509 Ma and accompanying look-up table for deriving numerical age. Journal of Geology, 109, 155-170.

Miller, K.G., Wright, J.D. \& FairbanKs, R.G. 1991. Unlocking the ice house: Oligocene-Miocene oxygen isotopes, eustasy, and margin erosion. Journal of Geophysical Research, 96, 6829-6848.

Mozer, A. 2012. Pre-glacial sedimentary facies of the Point Thomas Formation (Eocene) at Cytadela, Admiralty Bay, King George Island, West Antarctica. Polish Polar Research, 33, 41-62.

Mozer, A. 2013. Eocene sedimentary facies in a volcanogenic succession on King George Island, South Shetland Islands: a record of pre-ice sheet terrestrial environments in West Antarctica. Geological Quarterly, 57, 385-394.

Nawrocki, J., PańczyK, M. \& Williams, I.A. 2010. Isotopic ages and palaeomagnetism of selected magmatic rocks from King George Island (Antarctic Peninsula). Journal of the Geological Society of London, 167, 1063-1079.

Nawrocki, J., PańczyK, M. \& Williams, I.A. 2011. Isotopic ages of selected magmatic rocks from King George Island (West Antarctica) controlled by magnetostratigraphy. Geological Quarterly, 55, 301-322. 
Nawrocki, J., Pańczyk, M., Wójcik, K. \& KozŁowska-Roman, A. 2021a. Age of volcanism on Keller Peninsula and assessment of age-constrained volcanic activity on King George Island, South Shetland islands. Polish Polar Research (in press).

Nawrocki, J., Pańczyk, M., Wójcik, K. \& Tatur, A. 2021b. U-Pb isotopic ages and provenance of some far-travelled exotic pebbles from glaciogenic sediments of the Polonez Cove Formation (Oligocene, King George Island). Journal of the Geological Society, 178, 10.1144/jgs2020-113.

PańcZYK, M. \& NAWrocki, J. 2011. Geochronology of selected andesitic lavas from the King George Bay area (SE King George Island). Geological Quarterly, 55, 323-334.

PańcZYK, M., NaWrocki, J. \& Williams, I.S. 2009. Isotope age constraint for the Blue Dyke and Jardine Peak subvertical intrusions of King George Island, West Antarctica. Polish Polar Research, 30, 379-391.

Pankhurst, R.J. \& Smellie, J.L. 1983. K-Ar geochronology of the South Shetland Islands, Lesser Antarctica: apparent lateral migration of Jurassic to Quaternary island arc volcanism. Earth and Planetary Science Letters, 66, 214-222.

Paterson, S.R. \& Ducea, M.N. 2015. Arc magmatic tempos: gathering the evidence. Elements, 11, 91-98.

Paulo, A. \& Tokarski, A.K. 1982. Geology of the Turret Point-Three Sisters Point area, King George Island (South Shetland Islands, Antarctica). Studia Geologica Polonica, 74, 81-103.

Poole, I., Hunt, R.H. \& Cantrill, D. J. 2001. A fossil wood flora from King George Island: ecological implications for Antarctic Eocene vegetation. Annals of Botany, 88, 33-54.

PorębSKi, S.J. \& Gradziński, R. 1987. Depositional history of the Polonez Cove Formation (Oligocene), King George Island, West Antarctica: a record of continental glaciation, shallow marine sedimentation and contemporaneous volcanism. Studia Geologica Polonica, 93, 7-62.

PoręiBski, S.J. \& Gradziński, R. 1990. Lava fed Gilbert-type delta in the Polonez Cove Formation (Oligocene), King George Island, West Antarctica. International Association of Sedimentologists Special Publication, 10, 335-351.

Quaglio, F., Anelli, L.E., dos Santos, P.R., de Perinotto, J.A. \& Rocha-CAmpos, A.C. 2008. Invertebrates from the Low Head Member (Polonez Cove Formation, Oligocene) at Vauréal Peak, King George Island, West Antarctica. Antarctic Science, 20, 149-168.

Quaglio, F., Warren, L.V., Anelli, L.E., dos Santos, P.R., Rocha-Campos, A.C., Gaździcki, A., et al. 2014. Shell beds from the Low Head Member (Polonez Cove Formation, early Oligocene) at King George Island, west Antarctica: new insights on facies analysis, taphonomy and environmental significance. Antarctic Science, 26, 400-412.

Shen, Y. 1994. Subdivision and correlation of Cretaceous to Paleogene volcano-sedimentary sequence from Fildes Peninsula, King George Island, Antarctica. In SHEN, Y., ed. Stratigraphy and palaeontology of Fildes Peninsula, King George Island, Antarctica. State Antarctic Committee Monograph, 3. Beijing: Science Press, 29-36.

Shiling, H., Xiangshen, Z., Molan, E. \& Birkenmajer, K. 1996. ${ }^{40} \mathrm{Ar} /{ }^{39} \mathrm{Ar}$ and $\mathrm{K}-\mathrm{Ar}$ datings on the volcanic rocks in northern coast of King George Island, West Antarctica. Korean Journal of Polar Research, 7, 11-21.

Smellie, J.L. 2020. Antarctic Peninsula - geology and dynamic development. In KLeinschmidt, G., ed. Geology of the Antarctic continent. Stuttgart: Gebrüder Borntraeger Verlagsbuchhandlung, 18-86.
Smellie, J.L. 2021a. Antarctic volcanism - volcanology and palaeoenvironmental overview. In Smellie, J.L., Panter, K.S. \& Geyer, A., eds. Volcanism in Antarctica: 200 million years of subduction, rifting and continental break-up. London: Geological Society of London, Memoir (in press).

Smellie, J.L. 2021b. Bransfield Strait \& James Ross Island I. Volcanology. In Smellie, J.L., Panter, K.S. \& Geyer, A., eds. Volcanism in Antarctica: 200 million years of subduction, rifting and continental break-up. London: Geological Society of London, Memoir (in press).

Smellie, J.L. \& Rex, D.C. 1993. Age of oldest Tertiary continental glaciation on King George Island, South Shetland Islands, Antarctica. Quaternary Newsletter, 69, 64-66.

Smellie, J.L., Hunt, R.J., McIntosh, W.C. \& Esser, R.P. 2021. Lithostratigraphy, age and distribution of Eocene volcanic sequences on eastern King George Island, South Shetland Islands, Antarctica. Antarctic Science (in press).

Smellie, J.L., Millar, I.L., Rex, D.C. \& Butterworth, P.J. 1998. Subaqueous, basaltic lava dome and carapace breccia on King George Island, South Shetland Islands, Antarctica. Bulletin of Volcanology, 59, 245-261.

Smellie, J.L., Pankhurst, R.J., Thomson, M.R.A. \& Davies, R.E.S. 1984. The geology of the South Shetland Islands: VI. Stratigraphy, geochemistry and evolution. British Antarctic Survey Scientific Reports, 87, 1-85.

Soliani, E. \& Bonhomme, M.G. 1994. New evidence for Cenozoic resetting of $\mathrm{K}-\mathrm{Ar}$ ages in volcanic rocks of the northern portion of the Admiralty bay, King George Island. Antarctica. Journal of South American Earth Sciences, 7, 85-94.

Tokarski, A.K., PaOlo, A. \& Rubinowski, Z. 1981. Report on geological investigations of King George Island, South Shetland Islands (West Antarctica), in 1979/1980. Studia Geologica Polonica, 72, 133-140.

Troedson, A.L. \& Riding, J.B. 2002. Upper Oligocene to lowermost Miocene strata of King George Island, South Shetland Islands, Antarctica: stratigraphy, facies analysis, and implications for the glacial history of the Antarctic Peninsula. Journal of Sedimentary Research, 72, 510-523.

Troedson, A.L. \& Smellie, J.L. 2002. The Polonez Cove Formation of King George Island, Antarctica: stratigraphy, facies and implications for mid-Cenozoic cryosphere development. Sedimentology, 49, 277-301.

Warny, S., Kymes, C.M., Askin, R., Krajewski, K.P. \& Tatur, A. 2019. Terrestrial and marine floral response to latest Eocene and Oligocene events on the Antarctic Peninsula. Palynology, 43, 10.1080/ 01916122.2017.1418444.

Willan, R.C.R. \& Kelley, S.P. 1999. Mafic dyke swarms in the South Shetland Islands volcanic arc: unravelling multiepisodic magmatism related to subduction and continental rifting. Journal of Geophysical Research, 104, 23051-23068.

ZastaWniaK, E. 1981. Tertiary leaf flora from the Point Hennequin Group of King George Island (South Shetland IsIands, Antarctica) preliminary report. Geological Results of the Polish Antarctic Expeditions, 72, 97-112.

Zastawniak, E., Wrona, R., Gaździcki, A. \& Birkenmajer, K. 1985. Plant remains form the top part of the Point Hennequin Group (Upper Oligocene), King George Island (South Shetland Islands, Antarctica). Studia Geologica Polonica, 81, 143-164. 